\title{
Lipid-sensors, enigmatic-orphan and orphan nuclear receptors as therapeutic targets in breast-cancer
}

\author{
Enrico Garattini ${ }^{1}$, Marco Bolis ${ }^{1}$, Maurizio Gianni' ${ }^{1}$, Gabriela Paroni ${ }^{1}$, Maddalena \\ Fratelli $^{1}$ and Mineko Terao ${ }^{1}$ \\ ${ }^{1}$ Laboratory of Molecular Biology, IRCCS-Istituto di Ricerche Farmacologiche "Mario Negri", Milano, Italy \\ Correspondence to: Enrico Garattini, email: enrico.garattini@marionegri.it \\ Keywords: nuclear receptors, breast cancer, drug targets, chemo-prevention, treatment \\ Received: November 27, $2015 \quad$ Accepted: January 29, $2016 \quad$ Published: February 15, 2016
}

\section{ABSTRACT}

Breast-cancer is heterogeneous and consists of various groups with different biological characteristics. Innovative pharmacological approaches accounting for this heterogeneity are needed. The forty eight human Nuclear-Hormone-Receptors are ligand-dependent transcription-factors and are classified into Endocrine-Receptors, Adopted-Orphan-Receptors (Lipid-sensors and Enigmatic-Orphans) and Orphanreceptors. Nuclear-Receptors represent ideal targets for the design/synthesis of pharmacological ligands. We provide an overview of the literature available on the expression and potential role played by Lipid-sensors, Enigmatic-Orphans and Orphan-Receptors in breast-cancer. The data are complemented by an analysis of the expression levels of each selected Nuclear-Receptor in the PAM50 breast-cancer groups, following re-elaboration of the data publicly available. The major aim is to support the idea that some of the Nuclear-Receptors represent largely unexploited therapeutic-targets in breast-cancer treatment/chemo-prevention. On the basis of our analysis, we conclude that the Lipid-Sensors, NR1C3, NR1H2 and NR1H3 are likely to be onco-suppressors in breast-cancer. The Enigmatic-Orphans, NR1F1 NR2A1 and NR3B3 as well as the Orphan-Receptors, NROB1, NROB2, NR1D1, NR2F1, NR2F2 and NR4A3 exert a similar action. These Nuclear-Receptors represent candidates for the development of therapeutic strategies aimed at increasing their expression or activating them in tumor cells. The group of Nuclear-Receptors endowed with potential oncogenic properties consists of the Lipid-Sensors, NR1C2 and NR1I2, the Enigmatic-Orphans, NR1F3, NR3B1 and NR5A2, as well as the Orphan-Receptors, NR2E1, NR2E3 and NR6A1. These oncogenic Nuclear-Receptors should be targeted with selective antagonists, reverse-agonists or agents/strategies capable of reducing their expression in breast-cancer cells.

\section{INTRODUCTION}

Breast-cancer is heterogeneous and traditionally classified according to the expression of EstrogenReceptor-alpha (NR3A1/ER $\alpha)$, Progesterone-Receptor (NR3C3/PR) and/or HER2, the ERBB2 gene product. With these markers, breast-cancer is subdivided into ER-positive $\left(E R^{+}\right)$, HER2-positive $\left(H E R 2^{+}\right)$and triplenegative tumors. Genomic/transcriptomic data indicate that the number of breast-cancer groups is larger than originally assumed. The PAM50 gene-expression fingerprint classifies mammary-tumors in five groups, Basal, Her2, Luminal-A, Luminal-B and Normal-like, each having different biological characteristics and drugsensitivity [1]. A more recent classification further split PAM50 Basal cancer into Basal-like and Claudin-low tumors (Figure 1).

The superfamily of human Nuclear-HormoneReceptors (NRs) consists of forty eight members, which are ligand-dependent transcription-factors controlling the expression of specific gene-sets [2]. However, this is unlikely to represent their sole function, as transcriptionindependent activities are known for various NRs. NRs are encoded by distinct genes which, in many cases, give rise to different splicing-/protein-variants (Tables 1, 2, 3 ). The amino-acid sequences of human NRs are highly 
similar (Figure 2A) and contain up to six conserved structural regions (Figure 2B). The N-terminal A- and $\mathrm{B}$-regions are responsible for the ligand-independent transcriptional-activation-function (AF-1). The C-region contains the DNA-binding domain, while the D-region is unstructured. The E-region contains the ligand-bindingdomain and is responsible for the ligand-dependent transcriptional-activation-function (AF-2). The function of the C-terminal ill-conserved F-region is undefined. As the $\mathrm{C}$ - and E-regions are particularly important and structurally conserved, their position in NRs is indicated in Tables 1, 2, 3 .

Human NRs are classified into EndocrineReceptors, Adopted-Orphan-Receptors and Orphanreceptors according to the presence/absence of identified endogenous-ligands [3] (Tables 1, 2, 3). Endocrine-Receptors are divided into Steroid-Receptors and Heterodimeric-Receptors.

Steroid-Receptors include Estrogen-Receptor- $\alpha \quad(\mathrm{NR} 3 \mathrm{~A} 1 / \mathrm{ER} \alpha)$ and Estrogen-Receptor- $\beta \quad$ (NR3A2/ER $\beta), \quad$ ProgesteroneReceptor (NR3C3/PR), Androgen-Receptor (NR3C4/ AR), Mineralcorticoid-Receptor (NR3C2/MR) and Glucocorticod-Receptor (NR3C1/GR). The VitaminD-Receptor (NR1I1/VDR), Thyroid-Receptor-alpha (NR1A1/TR $\alpha$ ), Thyroid-Receptor-beta (NR1A2/TR $\beta$ ), Retinoic-Acid-Receptor-alpha (NR1B1/RAR $\alpha)$, RetinoicAcid-Receptor-beta (NR1B2/RAR $\beta$ ) and Retinoic-AcidReceptor-gamma (NR1B3/RAR $\gamma$ ) are HeterodimericReceptors. Adopted-Orphan-Receptors are split into Lipid-sensors and Enigmatic-Orphans.

Innovative pharmacological approaches taking into account the heterogeneity of breast cancer are needed. NRs represent ideal targets for the design/synthesis of pharmacological ligands. Indeed, the E-region

\section{A}
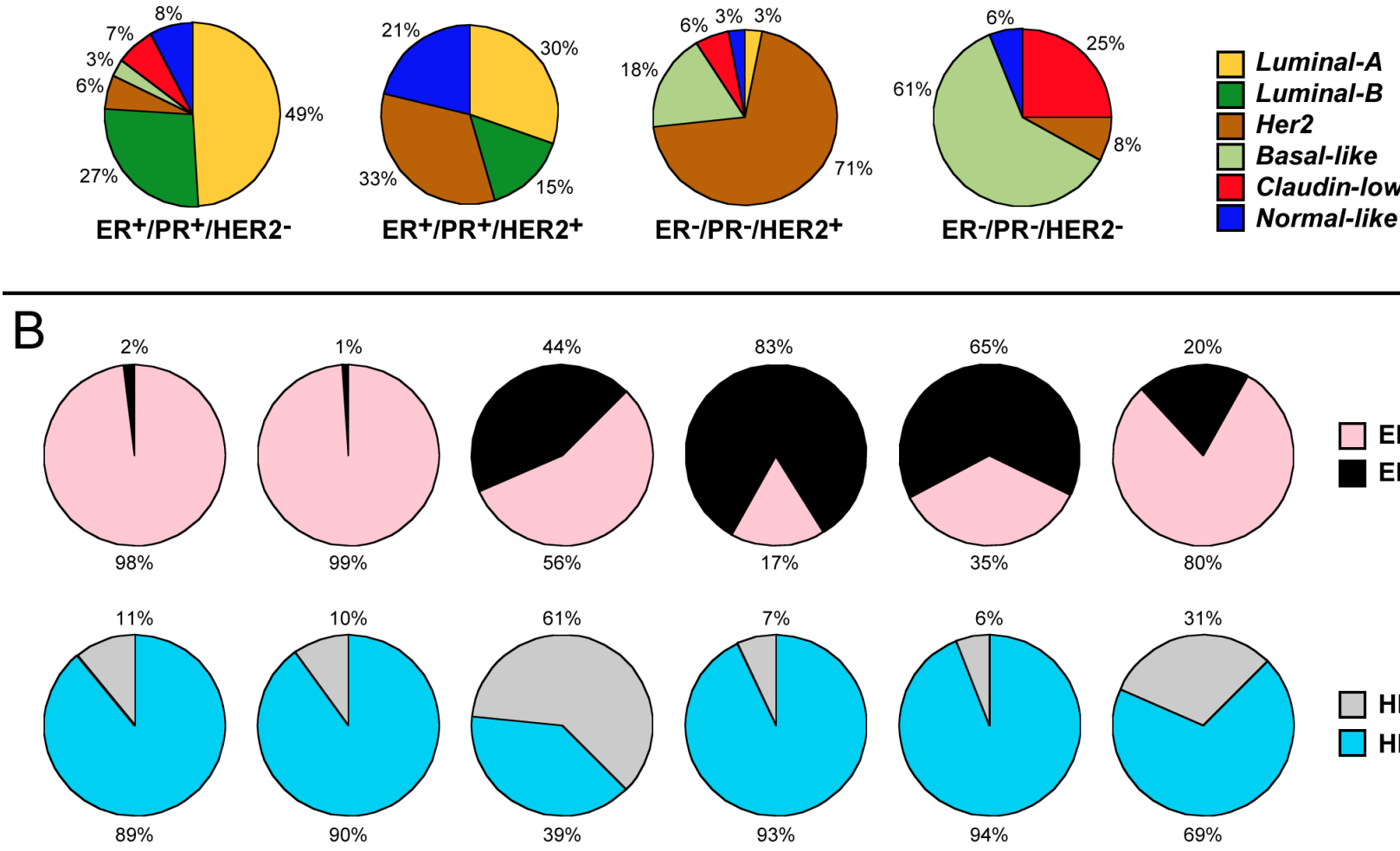

Luminal- $A$
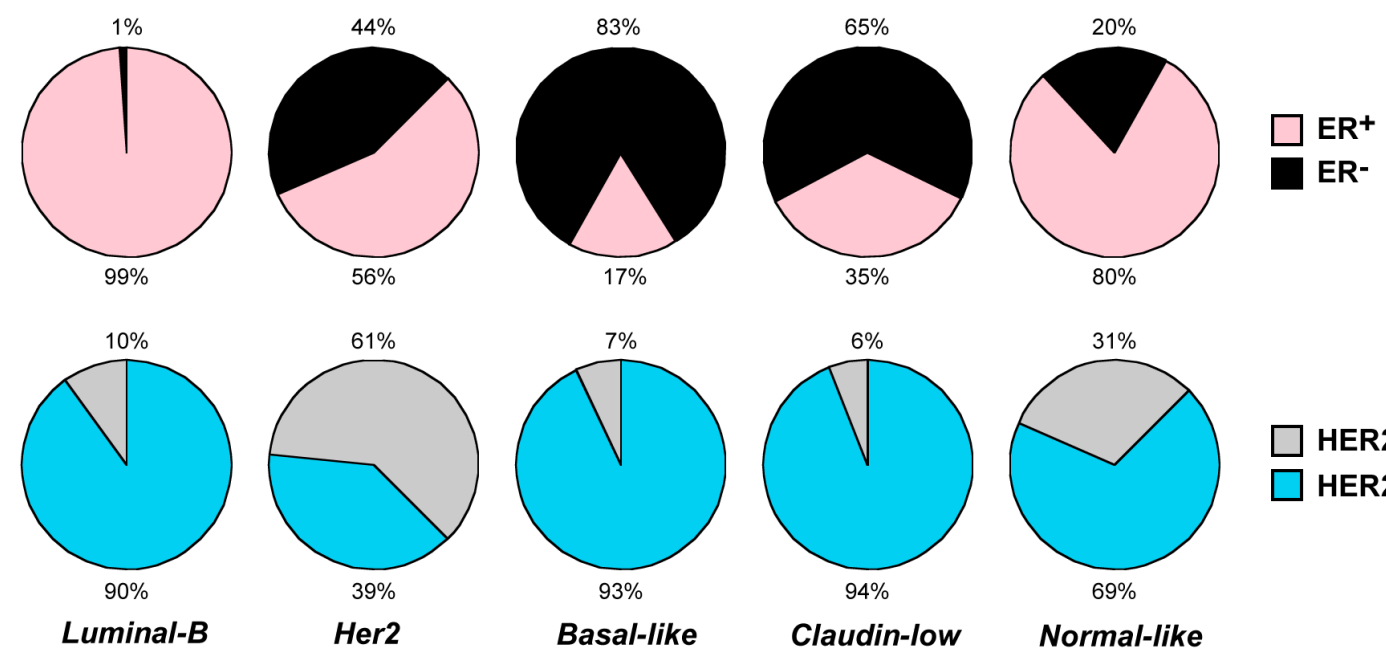

Figure 1: Correspondence between the PAM50 and the traditional classification of breast-cancer. A. Correspondence between the immuno-histochemical and the molecular/transcriptomic classification of breast cancer. Mammary-tumors are divided in four groups according to the traditional classification based on the immuno-histochemical determination of the ER $\alpha$, PR and HER2 molecular markers. For each of the four groups, the percentage of cases showing the six indicated transcriptomic phenotypes determined on the basis of a modification of the PAM50 fingerprint is illustrated. B. Expression of ER $\alpha$ (Upper circles) and HER2 (Lower circles) among the molecular/transcriptomic subtypes of breast cancer. Mammary tumors are split in six groups according the transcriptomic phenotype as detailed in A.. For each of the six groups the percentage of cases showing positivity to ER $\alpha$ is indicated. The results indicates that practically the totality of Luminal-A and Luminal-B tumors and the vast majority of the Normal-like ones are ER ${ }^{+}$. In contrast, the vast majority of Basal-like and Claudin-Low tumors, which are aggregated into the PAM50 Basal group, are ER- The data were obtained from the following article: Rivenbark AG, O'Connor SM, Coleman WB. Molecular and cellular heterogeneity in breast cancer: challenges for personalized medicine. Am J Pathol (2013) 183: 1113-24. 

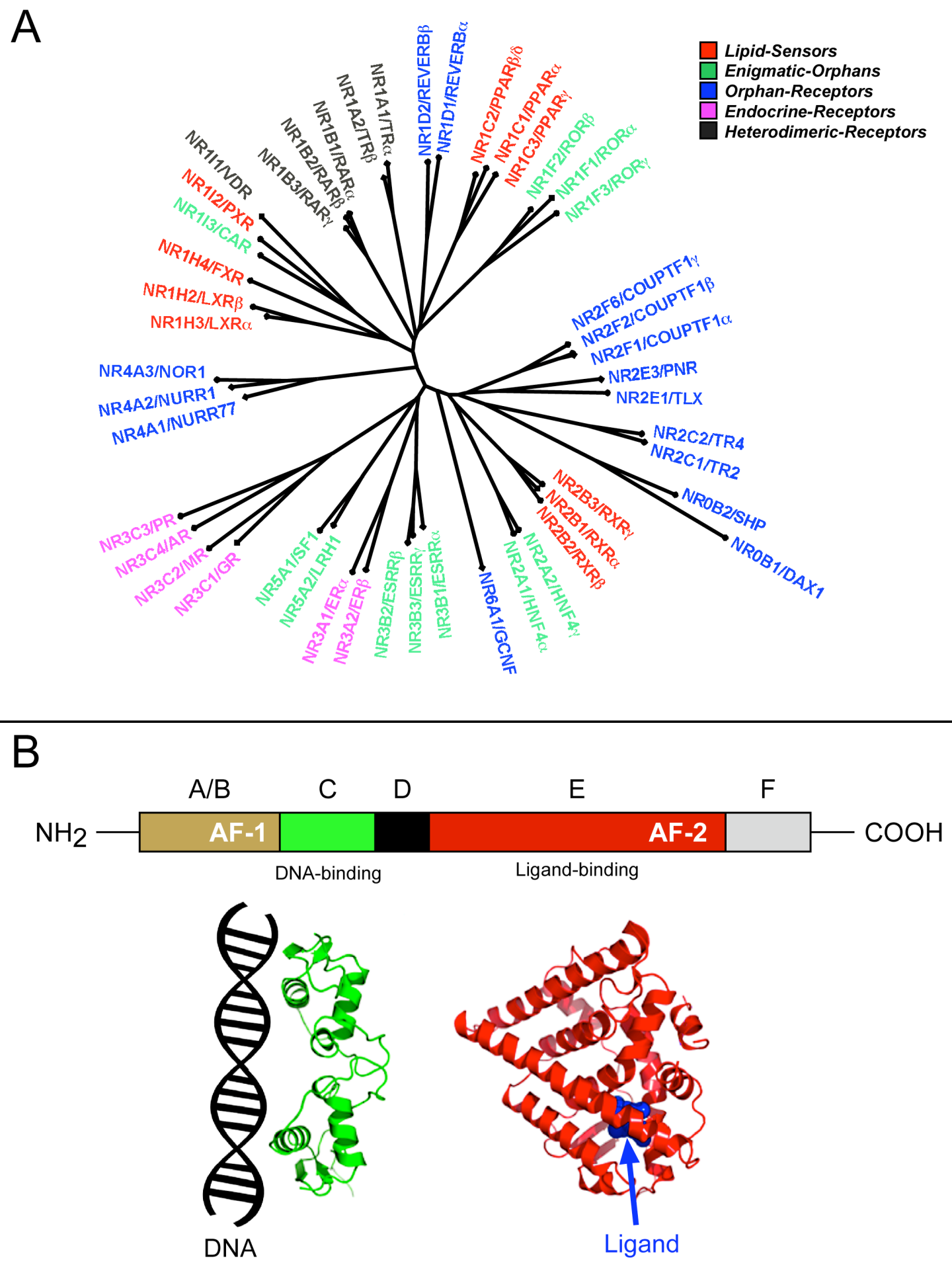

Figure 2: Phylogenetic tree and schematic structure of the human nuclear steroid receptors A. The panel illustrates an unrooted phylogenetic tree of the human nuclear steroid receptors. The phylogenetic tree was obtained following alignment of the amino acid sequences of the indicated nuclear receptors using the Clustal-omega algorithm (Sievers F, Wilm A, Dineen DG, Gibson TJ, Karplus K, Li W, Lopez R, McWilliam H, Remmert M, Söding J, Thompson JD, Higgins D. Fast, scalable generation of high-quality protein multiple sequence alignments using Clustal Omega Molecular Systems Biology 7 Article number: 539 doi:10.1038/msb.2011.75) B. The schematic structure of a typical nuclear receptor (NR) is shown in the upper diagram. The N-terminal A- and B-regions are responsible for the ligandindependent activation function (AF-1). The C-region contains the DNA-binding domain, while the unstructured D-region connects the $\mathrm{C}$ - and E-regions. The E-region containing the ligand-binding pocket is responsible for the ligand-dependent activation function (AF-2). The function of the $\mathrm{C}$-terminal F-region is undefined. The tridimensional structure of the $\mathrm{C}$ - and E-regions contained in a representative NR $(\mathrm{ER} \alpha)$ is illustrated in the lower part of the figure. 
accommodates only organic compounds and the design of new agonists/antagonists is facilitated by crystallographic data and functional screening assays. This article provides an overview of the literature available on the expression and role played by Lipid-sensors, Enigmatic-Orphans and Orphan-Receptors in breast-cancer induction/ progression. Steroid-Receptors, Heterodimeric-Receptors and the Lipid-sensors, Retinoid-X-Receptors (NR2B1/ $\mathrm{RXR} \alpha, \mathrm{NR} 2 \mathrm{~B} 2 / \mathrm{RXR} \beta, \mathrm{NR} 2 \mathrm{~B} 3 / \mathrm{RXR} \gamma$ ) are excluded from our analysis given the wealth of data on their therapeutic significance in breast-cancer $[4,5]$. The data are complemented by an analysis of the expression levels of each NR in the PAM50 breast-cancer groups, following re-elaboration of the data in the TCGA site (The-CancerGenome-Atlas: http://cancergenome.nih.gov). The review supports the idea that some of the NRs considered represent unexploited therapeutic-targets in breast-cancer treatment/chemo-prevention.

\section{LIPID-SENSORS}

The active transcriptional forms of Lipid-sensors are $R X R$ heterodimers. NRIC1-C3, NR1H2-4 and NRII2 are permissive heterodimeric partners, as the simultaneous presence of $N R 1$ and $R X R$ ligands results in cooperative responses[6].

\section{NR1C1 (PPAR $\alpha$ :peroxysome-proliferator -activated-receptor- $\alpha$ ), NRC2 (PPAR $\beta /$ $\delta$ :peroxysome-proliferator-activated-receptor-

$\beta / \delta)$ and NRC3 (PPAR $\gamma$ :peroxysome-
proliferator-activated-receptor-)

NR1C1, NRC2 and NR1C3 control lipid homeostasis. NR1C3 is the most studied member of the NR1C subfamily, given its relevance in obesity/ diabetes. The two NR1C2 shortest protein-variants

\section{Lipid-Sensors}
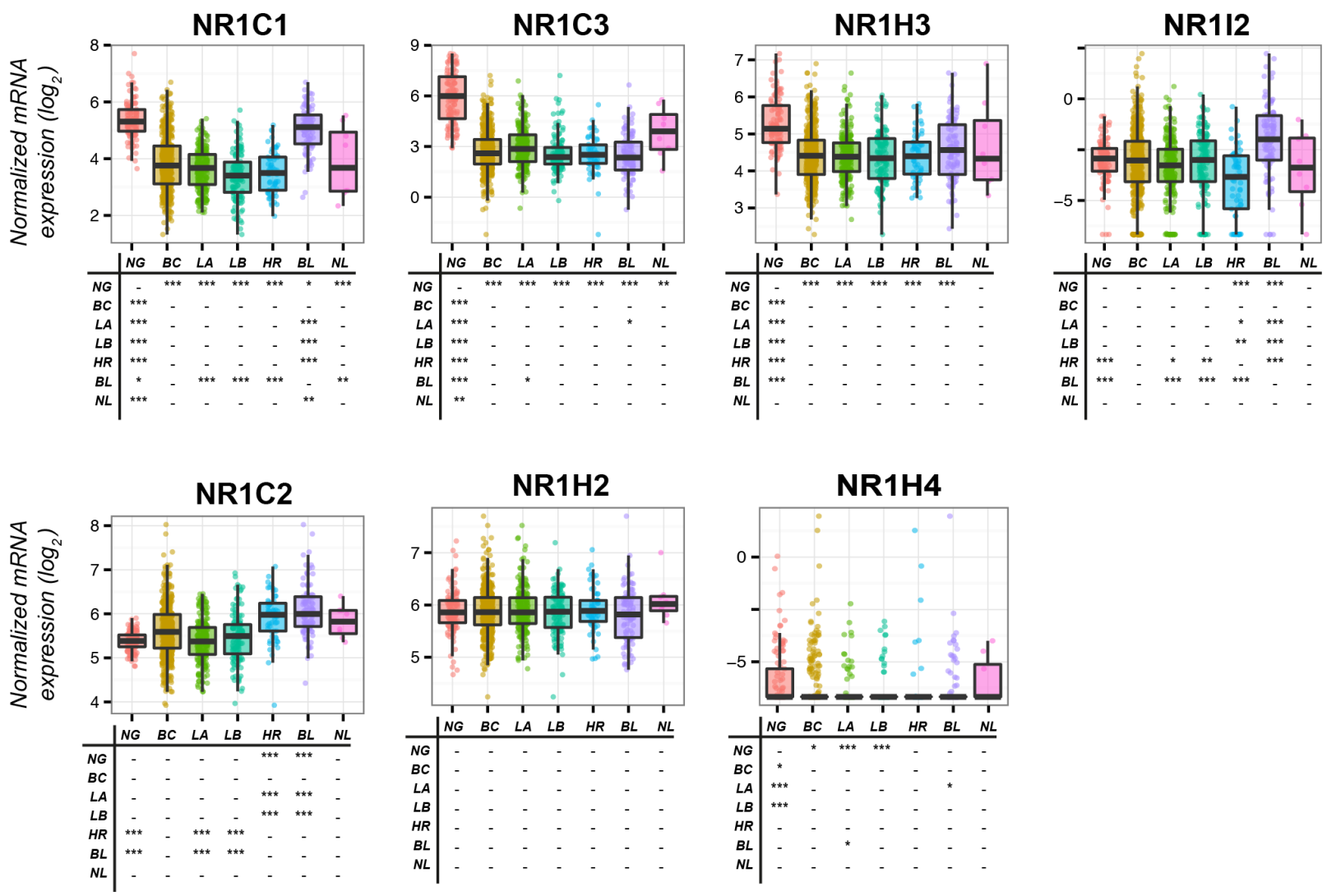

Figure 3: Expression of Lipid-sensors in normal mammary glands and breast-cancer tissue. The box-plots illustrate the expression of the indicated mRNAs belonging to the Lipid-sensors family of nuclear receptors (NRs) in normal mammary-glands ( $N G$ ), all breast-cancers $(B C)$ and Luminal-A $(L A)$, Luminal-B $(L B)$, HER2 (HR), Basal (BL) and Normal-like (NL) PAM50 mammary-tumors. Underneath each box-plot, the tables show significant differences in the mRNA expression levels of each NR between the indicated groups. The results were obtained from the data available in the TCGA (The Cancer Genome Atlas; http://cancergenome.nih.gov). Normalization, quantification and statistical analysis on raw sequencing counts was performed using the Limma/Voom (http://bioconductor.org) package in R statistical environment. * (adjusted $p<0.01$ ), ** (adjusted $p<0.001)$, *** (adjusted $p<0.0001$ ). 
Table 1: Human lipid sensors

\begin{tabular}{|c|c|c|c|c|c|c|c|c|}
\hline \multicolumn{8}{|c|}{ Lipid-Sensors } & \multirow[b]{2}{*}{$\begin{array}{l}\text { Predicted action in } \\
\text { breast-cancer }\end{array}$} \\
\hline Gene & $\begin{array}{l}\text { Chr } \\
\text { (No) }\end{array}$ & $\begin{array}{l}\text { Exons } \\
\text { (No) }\end{array}$ & Protein-variant & $\begin{array}{l}\text { Prot } \\
\text { (aa) }\end{array}$ & $\begin{array}{c}\text { DBD } \\
\text { (aa No) }\end{array}$ & $\begin{array}{c}\text { LBD } \\
\text { (aa No) }\end{array}$ & Ligands & \\
\hline $\begin{array}{c}\text { NRICl (PPAR } \alpha) \\
\text { Peroxysome-Proliferalor- } \\
\text { Activated-Receptor- } \alpha\end{array}$ & 22 & 8 & NP_001001928 & 468 & $101-184$ & $201-467$ & $\begin{array}{l}\text { 1-Palmitoyl-2-oleoyl-sn-glycero-3-phosphocholine (PUBCHEM:65167)(end. agonist) } \\
\text { Chakravarthy MV et al, Cell(2009)138:476-88 } \\
\text { CP775146 (PUBCHEM:10410059)(synth. agonist) Kane CD et al, Mol Pharmacol } \\
\text { (2009)75:296-306 } \\
\text { GW6471 (PUBCHEM:446738)(synth. antagonist) Muller MQ et al, J Med Chem } \\
\text { (2009)52:2875-9 }\end{array}$ & Mixed results \\
\hline $\begin{array}{l}\text { NRIC2 (PPAR } \beta / \delta) \\
\text { Peroxysome-Proliferator- } \\
\text { Activated-Receptor- } \beta / \delta\end{array}$ & 6 & $\begin{array}{l}8 \\
7 \\
6 \\
8\end{array}$ & $\begin{array}{c}\text { NP_006229 } \\
\text { NP_001165290 } \\
\text { NP_001165291 } \\
\text { NP_803184 }\end{array}$ & $\begin{array}{l}441 \\
402 \\
343 \\
361\end{array}$ & $\begin{array}{c}73-156 \\
34-117 \\
41-58 \\
73-156\end{array}$ & $\begin{array}{c}173-440 \\
134-401 \\
75-342 \\
173-359\end{array}$ & $\begin{array}{l}\text { PGI2 (PUBCHEM:23702145)(end. agonist) Gupta RA et al, Proc Natl Acad Sci US A } \\
\text { (2000)97:13275-80 } \\
\text { 15-HETE (PUBCHEM:9966861)(end. agonist) Naruhn S et al, Mol Pharmacol (2010) } \\
\text { 77:171-84 } \\
\text { Fatty-acids (end. agonists) Barish GD et al, J Clin Invest (2006)1 16:590-7 } \\
\text { GW0742 (PUBCHEM:9934458)(synth. agonist) Sznaidman L et al, Bioorg Med Chem Lett } \\
\text { (2003)13:1517-21 } \\
\text { GSK3787 (PUBCHEM:2800647)(synth. antagonist) Palkar PS et al, Mol Pharmacol } \\
\text { (2010)78:419-30 }\end{array}$ & $\begin{array}{c}\begin{array}{c}\text { Oncogenic } \\
\text { action }\end{array} \\
\text { Her } 2 \text { tumors }\end{array}$ \\
\hline $\begin{array}{c}\text { NRIC3 (PPAR } \gamma) \\
\text { Peroxysome-Proliferator- } \\
\text { Activated-Receptor- }-\gamma\end{array}$ & 3 & $\begin{array}{l}8 \\
7\end{array}$ & $\begin{array}{l}\text { NP_619725 } \\
\text { NP_056953 }\end{array}$ & $\begin{array}{l}477 \\
505\end{array}$ & $\begin{array}{l}110-193 \\
138-221\end{array}$ & $\begin{array}{l}209-476 \\
237-504\end{array}$ & $\begin{array}{l}\text { 15-deoxy- } \Delta 12,14-\mathrm{PGJ} 2 \text { (PUBCHEM:5311211)(end. agonist) Kotta-Loizou IC et al, } \\
\text { Anticancer Agents Med Chem (2012)12:1025-44 } \\
\text { Unsatur. fatty-acids (end. agonists) } \\
\text { Troglitazone (PUBCHEM:5591)(synth. agonists) Kodera Y et al, } \boldsymbol{J} \text { Biol Chem } \\
\text { (2000)275:33201-4 } \\
\text { BADGE (PUBCHEM:3479589)(synth. antagonist) Bishop-Bailey D et al, Br J Pharmacol } \\
(2000) \text { 131:651-4 }\end{array}$ & $\begin{array}{l}\text { Onco-suppressive } \\
\text { action }\end{array}$ \\
\hline $\begin{array}{l}\text { NR1H2 (LXR } \beta) \\
\text { Liver-X-Receptor- } \beta\end{array}$ & 19 & $\begin{array}{l}10 \\
9\end{array}$ & $\begin{array}{c}\text { NP_009052 } \\
\text { NP_001243576 }\end{array}$ & $\begin{array}{l}461 \\
364\end{array}$ & $\begin{array}{c}67-163 \\
-\end{array}$ & $\begin{array}{l}224-459 \\
127-362\end{array}$ & $\begin{array}{l}\text { 27-hydroxycholesterol (PUBCHEM:123976)(end. agonist) Song C et al, Steroids } \\
\text { (2000)65:423-7 } \\
\text { Oxysterols (end. agonists) Zhao C and Dahlman-Wright K, J Endocrinol (2010)204:233-40 } \\
\text { GW3965 (PUBCHEM:447905)(synth. agonist) Collins JL et al, J Med } \\
\text { Chem(2002)45:1963-6 } \\
\text { GSK2033 (PUBCHEM:46203250)(synth. antagonist) Zuercher WJ et al, J Med Chem } \\
\text { (2010)53:3412-6 }\end{array}$ & $\begin{array}{l}\text { Onco-suppressive } \\
\text { action }\end{array}$ \\
\hline $\begin{array}{l}\text { NR1H3 }(\mathrm{LXR} \alpha) \\
\text { Liver-X-Receptor-a }\end{array}$ & 11 & $\begin{array}{c}10 \\
10 \\
9 \\
9\end{array}$ & $\begin{array}{c}\text { NP_001238863 } \\
\text { NP_005684 } \\
\text { NP_001123574 } \\
\text { NP_001123573 }\end{array}$ & $\begin{array}{l}453 \\
447 \\
402 \\
387\end{array}$ & $\begin{array}{l}84-184 \\
78-178 \\
33-133 \\
78-187\end{array}$ & $\begin{array}{l}216-451 \\
210-445 \\
165-400 \\
210-385\end{array}$ & $\begin{array}{l}\text { 27-hydroxycholesterol (PUBCHEM:123976)(end. agonist) Song C et al, Steroids } \\
\text { (2000)65:423-7 } \\
\text { Oxysterols (end. agonists) Zhao C and Dahlman-Wright K, J Endocrinol (2010)204:233-40 } \\
\text { GW3965 (PUBCHEM:447905)(synth. agonists) Collins JL et al, J Med } \\
\text { Chem(2002)45:1963-6 } \\
\text { GSK2033 (PUBCHEM:46203250)(synth. antagonist) Zuercher WJ et al, J Med Chem } \\
\text { (2010)53:3412-6 }\end{array}$ & $\begin{array}{l}\text { Onco-suppressive } \\
\text { action }\end{array}$ \\
\hline $\begin{array}{c}\text { NRIH4 }(\mathrm{FXR}) \\
\text { Farnesoid-X-Receptor }\end{array}$ & 12 & $\begin{array}{l}11 \\
11 \\
10 \\
9 \\
9\end{array}$ & $\begin{array}{c}\text { NP_005114 } \\
\text { NP_001193908 } \\
\text { NP_001193907 } \\
\text { NP_001193921 } \\
\text { NP_001193922 }\end{array}$ & $\begin{array}{l}472 \\
476 \\
425 \\
482 \\
486\end{array}$ & $\begin{array}{l}124-207 \\
124-211 \\
127-149 \\
134-217 \\
134-221\end{array}$ & $\begin{array}{l}247-467 \\
251-471 \\
200-420 \\
252-470 \\
256-474\end{array}$ & $\begin{array}{l}\text { Deoxycholate (PUBCHEM:23668196)(end. agonist) Silva J et al, J Lipid Res (2006) 47:724- } \\
33 \\
\text { Chenodeoxycholic-acid (PUBCHEM:10133)(end. agonist) Makishima M et al, Science } \\
\text { (1999) 284:1362-5 } \\
\text { GW4064 (PUBCHEM:9893571)(synth. agonist) Maloney PR et al, J Med Chem (2000) } \\
\text { 43:2971-4 } \\
\text { guggulsterone (PUBCHEM:6439929)(synth. antagonist) Owsley E and Chiang JY, Biochem } \\
\text { Biophys Res Commun (2003) 304:191-5 }\end{array}$ & Mixed results \\
\hline $\begin{array}{c}\text { NRII2 (PXR) } \\
\text { Pregnane-X-Receptor }\end{array}$ & 3 & $\begin{array}{l}9 \\
9 \\
9\end{array}$ & $\begin{array}{l}\text { NP_003880 } \\
\text { NP_148934 } \\
\text { NP_071285 }\end{array}$ & $\begin{array}{l}434 \\
397 \\
473\end{array}$ & $\begin{array}{l}40-127 \\
40-127 \\
79-166\end{array}$ & $\begin{array}{l}143-428 \\
143-391 \\
182-467\end{array}$ & $\begin{array}{l}\text { Rifampicin (PUBCHEM:6913622)(synth. agonist) Moore LB et al, J Biol Chem (2000) } \\
\text { 275:15122-7 } \\
\text { SR12813 (PUBCHEM:446313) (synth. agonist) Lemaire G et al, Mol Pharmacol (2007) } \\
\text { 72:572-81 } \\
\text { Meclizine (PUBCHEM:4034)(synth. antagonist) Lau AJ ef al, J Pharmacol Exp Ther(2011) } \\
\text { 336:816-26 }\end{array}$ & $\begin{array}{l}\text { Oncogenic } \\
\text { action }\end{array}$ \\
\hline
\end{tabular}

The table contains basic information on the characteristics of the Lipid-Sensors group of nuclear receptors (NRs). The first column lists the human NRs considered in the review article. The official symbol of each NR is indicated in italics, while the original alias of each protein product is indicated in parenthesis. The full name of each NR is indicated underneath in italics. The second column from the left lists the human chromosome (Chr) each NR maps to. The number of exons encoding the transcripts giving rise to the corresponding NR protein-variant is indicated in the third column. The fourth column lists the accession number of each NR protein-variant. The amino acid (aa) length of each NR protein variant, the position of the DNA-binding domain (DBD) and the ligand-binding domain (LBD) are indicated in columns five, six and seven, respectively. Column eight contains a list of representative endogenous (end.) and synthetic (synth.) agonists, antagonists and reverse agonists for each NR along with an appropriate reference. The chemical structures of the listed molecules can be found in the PUBCHEM database with the use of the PUBCHEM-CID accession numbers provided. The PUBCHEM chemical structure is not available in the case of the NR2E1 agonists Ccrp-1, -2 and -3. When possible, the predicted onco-suppressive (bold) or oncogenic (black-boxed) action of the corresponding NR is indicated in the last column on the right. Synthetic agonists and antagonists of potential therapeutic interest targeting onco-suppressive and oncogenic NRs, respectively, are marked in bold and boxed in black. Finally, in the few cases where supportive data are available, the type of breast-cancer which is predicted to represent a preferential target of the NR is listed in the last column.

present with incomplete DNA- and Ligand-binding domains, respectively (Table 1). The only identified endogenous NR1C1 activator is 1-palmitoyl-2-oleoylsn-glycerol-3-phosphocholine (POGP). ProstaglandinPGI2, 15-hydroxyeicosatetraenoic-acid (15-HETE) and polyunsaturated fatty-acids are recognized endogenous NRIC2 ligands. Certain prostaglandins and fatty-acids act as endogenous NR1C3 ligands. Some of the numerous synthetic agonists/antagonists available are listed in Table 1. NR1C1-mRNA (UNIGENE-Hs.103110), NR1C2-
mRNA (UNIGENE-Hs.696032) and NR1C3-mRNA (UNIGENE-Hs.162646) expression is ubiquitous and the transcripts are detectable in mammary-glands, albeit at very low levels in the case of NR1C1. Relative to the normal counterpart, NR1C1 and NR1C3 mRNAs are down-regulated in all PAM50-classified breast-cancers (Figure 3). Basal and Normal-like tumors show the highest NR1C1 and NR1C3 levels, respectively. In contrast, mammary-tumors express higher NR1C2 mRNA levels than the normal counterpart, due to up-regulation in Her2, 
Table 2: Human enigmatic orphans

\begin{tabular}{|c|c|c|c|c|c|c|c|c|}
\hline \multicolumn{8}{|c|}{ Enigmatic-Orphans } & \multirow[b]{2}{*}{$\begin{array}{l}\text { Onco-suppressive } \\
\text { action } \\
\text { ER' tumors }\end{array}$} \\
\hline $\begin{array}{l}\text { NRIFI (ROR } \alpha) \\
\text { RAR-Related-Orphan- } \\
\text { Receptor- } \alpha\end{array}$ & 15 & $\begin{array}{l}11 \\
12 \\
11\end{array}$ & $\begin{array}{l}\text { NP_599023 } \\
\text { NP_599022 } \\
\text { NP_002934 }\end{array}$ & $\begin{array}{l}523 \\
556 \\
548\end{array}$ & $\begin{array}{l}66-160 \\
99-193 \\
91-185\end{array}$ & $\begin{array}{l}272-523 \\
305-544 \\
297-536\end{array}$ & $\begin{array}{l}\text { ATRA (PUBCHEM: 444795)(end.agonist) Stehlin-Gaon C et al, Nat Struct Biol (2003)10: } \\
\text { 820-5. } \\
\text { Melatonin (PUBCHEM:896)(end.agonist) Dai J et al, Mol Cell Endocrinol (2001)176:111- } \\
20 \\
\text { SR1078 (PUBCHEM:17980288)(synth. agonist) Kojetin D et al, ACS Chem Biol (2011) } \\
\text { 6:131-4 } \\
\text { SR1001 (PUBCHEM:44241473)(synth.antagonist) Solt LA et al, Nature(2011 )472: 491-4 }\end{array}$ & \\
\hline $\begin{array}{c}N R I F 2 \text { (ROR } \beta) \\
\text { RAR-Related-Orphan- } \\
\text { Receptor- } \beta\end{array}$ & 9 & 10 & NP_008845 & 459 & 3-97 & $210-450$ & $\begin{array}{l}\text { Unknown end. agonists } \\
\text { N-[5-(2-chloro-benzoyl)-4-(3-chlorophenyl)-thiazol-2-yl]-2-(4-ethanesulfonyl-phenyl)- } \\
\text { acetamide (PUBCHEM:8813095)(synth. reverse agonist) Gege C et al Bioorg Med Chem } \\
\text { Lett (2014)24:5265-7 }\end{array}$ & Unknown \\
\hline $\begin{array}{c}\text { NR1F3(ROR } \gamma) \\
\text { RAR-Related-Orphan- } \\
\text { Receptor-y' }\end{array}$ & 1 & $\begin{array}{l}10 \\
11\end{array}$ & $\begin{array}{l}\text { NP_001001523 } \\
\text { NP_005051 }\end{array}$ & $\begin{array}{l}497 \\
518\end{array}$ & $\begin{array}{c}4-97 \\
24-118\end{array}$ & $\begin{array}{l}247-485 \\
268-506\end{array}$ & $\begin{array}{l}\text { 7ק,27-dihydroxycholesterol (PUBCHEM:24895774)(end.agonist) Soroosh P et al, Proc Natl } \\
\text { Acad Sci U S A (2014)111:12163-8. } \\
\text { SR2211 (PUBCHEM:51035449)(synth. antagonist) Kumar N et al, ACS Chem Biol (2012) } \\
\text { 7:672-7) } \\
\text { N-[5-(2-chloro-benzoyl)-4-(3-chlorophenyl)-thiazol-2-yl]-2-(4-ethanesulfonyl-phenyl)-- } \\
\text { acetamide (PUBCHEM:8813095)(synth. reverse agonist) Gege C et al Bioorg Med Chem } \\
\text { Lett (2014)24:5265-7) }\end{array}$ & $\begin{array}{l}\text { Oncogenic } \\
\text { Action } \\
\text { ER' tumors }\end{array}$ \\
\hline $\begin{array}{c}\text { NRII3 (CAR) } \\
\text { Constitutive-Androstane- } \\
\text { Receptor }\end{array}$ & 1 & $\begin{array}{l}9 \\
9 \\
9 \\
9 \\
8 \\
8 \\
8 \\
8 \\
8 \\
8 \\
8 \\
7 \\
7\end{array}$ & $\begin{array}{c}\text { NP_005113 } \\
\text { NP_001070950 } \\
\text { NP_001070948 } \\
\text { NP_001070937 } \\
\text { NP_001070940 } \\
\text { NP_001070949 } \\
\text { NP_001070947 } \\
\text { NP_01070939 } \\
\text { NP_001070942 } \\
\text { NP_001070944 } \\
\text { NP_001070945 } \\
\text { NP_-001070938 } \\
\text { NP-001070943 }\end{array}$ & \begin{tabular}{l|l}
348 \\
357 \\
352 \\
340 \\
324 \\
314 \\
319 \\
309 \\
296 \\
311 \\
306 \\
280 \\
267
\end{tabular} & $\begin{array}{c}11-82 \\
11-82 \\
11-82 \\
11-82 \\
7-53 \\
11-82 \\
7-53 \\
11-82 \\
11-82 \\
7-53 \\
7-53 \\
7-53 \\
7-53\end{array}$ & \begin{tabular}{c|}
$106-346$ \\
$106-355$ \\
$106-350$ \\
$106-311$ \\
$77-322$ \\
$106-312$ \\
$77-317$ \\
$106-307$ \\
$106-267$ \\
$77-282$ \\
$77-277$ \\
$77-278$ \\
$77-238$
\end{tabular} & $\begin{array}{l}\text { Androstenol (PUBCHEM:101989)(end. antagonist) Makinen J et al, Biochem J (2003) } \\
\text { 376:465-72 } \\
\text { CITCO (PUBCHEM:9600409)(synth. agonist) Maglich JM et al, J Biol Chem (2003) } \\
\text { 278:17277-83. } \\
\text { TCPOBOP (PUBCHEM:5382)(synth. agonist) Yamamoto Y et al, PLoS One (2010) } \\
\text { 5:e10121 } \\
\text { BDBM50422490 (CHEMBL141998) (synth. antagonist) Jyrkkarinne J et al, J Med Chem } \\
\text { (2003) 46: 4687-95. }\end{array}$ & Unknown \\
\hline $\begin{array}{c}\text { NR2AI (HNF4 } 4) \\
\text { Hepatocyte-Nuclear-Factor-4a }\end{array}$ & 20 & $\begin{array}{l}10 \\
11 \\
10 \\
8 \\
10 \\
10 \\
8\end{array}$ & $\begin{array}{l}\text { NP_001245284 } \\
\text { NP_001274112 } \\
\text { NP_849180 } \\
\text { NP_849181 } \\
\text { NP_787110 } \\
\text { NP_001025174 } \\
\text { NP-001274113 }\end{array}$ & $\begin{array}{l}467 \\
449 \\
464 \\
417 \\
452 \\
442 \\
395\end{array}$ & $\begin{array}{l}53-128 \\
35-110 \\
60-135 \\
60-135 \\
38-113 \\
38-113 \\
35-110\end{array}$ & $\begin{array}{l}144-366 \\
126-348 \\
151-373 \\
151-373 \\
129-351 \\
129-351 \\
126-348\end{array}$ & $\begin{array}{l}\text { Linoleic-acid (PUBCHEM:5280450)(end. agonist) Yuan X et al, PLoS One (2009) } \\
\text { 4:e5609. }\end{array}$ & $\begin{array}{l}\text { Onco-suppressive } \\
\text { action }\end{array}$ \\
\hline $\begin{array}{c}\text { NR2A2 (HNF4 } \gamma) \\
\text { Hepatocyte-Nuclear-Factor-4 } 4 \gamma\end{array}$ & 8 & 10 & NP_004124 & 445 & $49-124$ & $140-361$ & Fatty-acids (end. agonists) Sladek F, Mol Cell (2002) 10:219-21 & Unknown \\
\hline $\begin{array}{c}\text { NR3BI (ESRR } \alpha) \\
\text { Estrogen-Related-Receptor- } \alpha\end{array}$ & 11 & 7 & NP_001269379 & 423 & $73-168$ & $197-420$ & $\begin{array}{l}\text { Diethylstilbestrol (PUBCHEM:448537)(end. agonist) Ariazi EA and Jordan VC, Curr Top } \\
\text { Med Chem (2006) 6:203-15 }\end{array}$ & $\begin{array}{l}\text { Oncogenic } \\
\text { Action }\end{array}$ \\
\hline & & & & & & & $\begin{array}{l}\text { SR16388 (PUBCHEM:54612678)(synth. antagonist) Duellman SJ et al, Biochem } \\
\text { Pharmacol (2010) 80:819-26 } \\
\text { XCT790 (PUBCHEM:6918788)(synth. antagonist) Lanvin O et al, J Biol Chem (2007) } \\
\text { 282:28328-34 }\end{array}$ & $\begin{array}{l}\text { Her } 2 \text { tumors } \\
\text { Basal tumors }\end{array}$ \\
\hline $\begin{array}{c}N R 3 B 2(\mathrm{ESRR} \beta) \\
\text { Estrogen-Related-Receptor- } \beta\end{array}$ & 14 & 10 & NP_004443 & 508 & $98-193$ & $212-431$ & $\begin{array}{l}\text { Diethylstilbestrol (PUBCHEM:448537)(end. agonist) Ariazi EA and Jordan VC, Curr Top } \\
\text { Med Chem (2006) 6:203-15 } \\
\text { DY131 (PUBCHEM:5497124)(synth. agonist) Yu DD and Forman BM, Bioorg Med } \\
\text { Chem Lett (2005) 15:1311-3 }\end{array}$ & $\begin{array}{l}\text { Onco-suppressive } \\
\text { action }\end{array}$ \\
\hline $\begin{array}{c}N R 3 B 3(\text { ESRR } \gamma) \\
\text { Estrogen-Related-Receptor- } \gamma\end{array}$ & 1 & $\begin{array}{l}9 \\
8 \\
7 \\
8\end{array}$ & $\begin{array}{l}\text { NP_001230448 } \\
\text { NP_001230447 } \\
\text { NP_001429 } \\
\text { NP_001230436 }\end{array}$ & $\begin{array}{l}435 \\
470 \\
458 \\
396\end{array}$ & $\begin{array}{c}99-195 \\
127-223 \\
122-218 \\
99-156\end{array}$ & $\begin{array}{l}214-433 \\
249-468 \\
237-456 \\
175-394\end{array}$ & $\begin{array}{l}\text { Diethylstilbestrol (PUBCHEM:448537)(end. agonist) Ariazi EA and Jordan VC, Curr Top } \\
\text { Med Chem (2006) 6:203-15 } \\
\text { GSK4716 (PUBCHEM:5331325)(synth. agonist) Zuercher WJ et al, J Med Chem } \\
\text { (2005) } 48 \text { : } 3107-9 \\
\text { GSK9089 (PUBCHEM:5497124)(synth. agonist) Zuercher WJ et al, J Med Chem } \\
\text { (2005) 48: 3107-9 }\end{array}$ & $\begin{array}{l}\text { Onco-suppressive } \\
\text { action }\end{array}$ \\
\hline $\begin{array}{l}\text { NR5AI (SF-1) } \\
\text { Steroidogenic-Factor-1 }\end{array}$ & 9 & 7 & NP_004950 & 461 & $13-105$ & $223-459$ & $\begin{array}{l}\text { phosphatidic-acid (PUBCHEM: 5283523)(end. agonist) Krylova IN et al, Cell (2005) } \\
\text { 120:343-55 } \\
\text { phosphatidyl-choline (PUBCHEM: 5287971)(end. agonist) Sablin EP et al, Mol Endocrinol } \\
\text { (2009) 23: 25-34 } \\
\text { GSK8470 (PUBCHEM:10883540)(synth. agonist) Whitby RJ et al, J Med Chem (2006) 49: } \\
\text { 6652-5 } \\
\text { AC-45594 (PUBCHEM:25641)(synth. antagonist) Del Tredici AL et al, Mol Pharmacol } \\
\text { (2008) 73: 900-8 }\end{array}$ & Unknown \\
\hline $\begin{array}{c}\text { NR5A2 (LRH-1) } \\
\text { Liver-Receptor-Homolog-l }\end{array}$ & 1 & $\begin{array}{l}8 \\
7 \\
7\end{array}$ & $\begin{array}{c}\text { NP_995582 } \\
\text { NP_001263393 } \\
\text { NP_003813 }\end{array}$ & $\begin{array}{l}541 \\
469 \\
495\end{array}$ & $\begin{array}{l}86-178 \\
14-106 \\
40-132\end{array}$ & $\begin{array}{l}342-390 \\
229-469 \\
255-495\end{array}$ & $\begin{array}{l}\text { phosphatidic-acid (PUBCHEM: 5283523)(end. agonist) Krylova IN et al, Cell (2005) } \\
\text { 120:343-55 } \\
\text { GSK8470 (PUBCHEM:10883540)(synth. agonist) Whitby RJ et al, J Med Chem (2006) 49: } \\
6652-5\end{array}$ & $\begin{array}{l}\text { Oncogenic } \\
\text { action }\end{array}$ \\
\hline
\end{tabular}

The table contains basic information on the Enigmatic-Orphans group of nuclear receptors (NRs). The first column lists the human NRs considered in the review article. The official symbol of each NR is indicated in italics, while the original alias of each protein product is indicated in parenthesis. The full name of each NR is indicated underneath in italics. The second column from the left lists the human chromosome (Chr) each NR maps to. The number of exons encoding the transcripts giving rise to the corresponding NR protein-variant is indicated in the third column. The fourth column lists the accession number of each NR protein-variant. The amino acid (aa) length of each NR protein variant, the position of the DNA-binding domain (DBD) and the ligand-binding domain (LBD) are indicated in columns five, six and seven, respectively. Column eight contains a list of representative endogenous (end.) and synthetic (synth.) agonists, antagonists and reverse agonists for each NR along with an appropriate reference. The chemical structures of the listed molecules can be found in the PUBCHEM database with the use of the PUBCHEM-CID accession numbers provided. The structure of the NR1I3 antagonist, BDBM50422490, is available in the CHEMBL database as indicated. When possible, the predicted onco-suppressive (bold) or oncogenic (black-boxed) action of the corresponding NR is indicated in the last column on the right. Synthetic agonists and antagonists of potential therapeutic interest targeting onco-suppressive and oncogenic NRs, respectively, are marked in bold and boxed in black. Finally, in the few cases where supportive data are available, the type of breast-cancer which is predicted to represent a preferential target of the NR is listed in the last column. 
Basal and Normal-like cancers.

It is unclear whether NR1C1 has oncogenic or an oncosuppressive properties, as mixed evidence is available. Ligand-dependent NR1C1 activation increases the proliferation of $\mathrm{ER}^{-} / M D A-M B 231$ and $\mathrm{ER}^{+} / M C F-$ 7 cells [7]. In addition, the NRIC1-ligand, Wy14643, promotes tumor-mammosphere formation[8]. Despite this evidence, the NR1C1-agonist, hydroxyeicosatetraenoic-

Enigmatic-Orphans

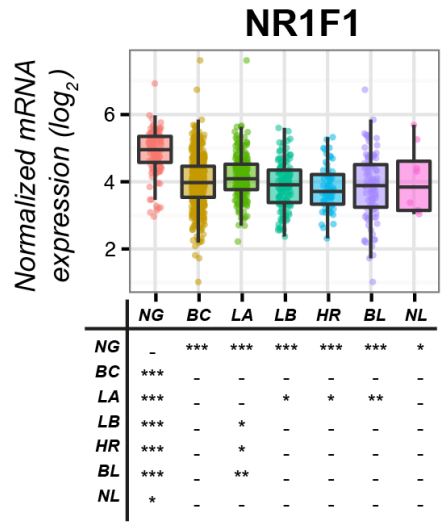

NR1F2

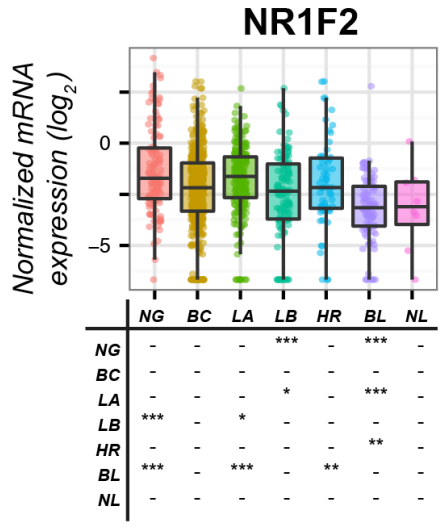

NR1F3

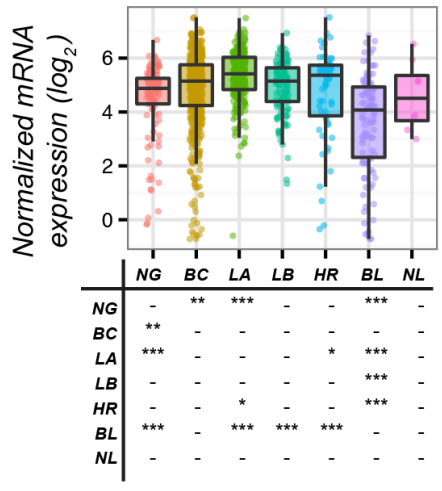

NR1/3

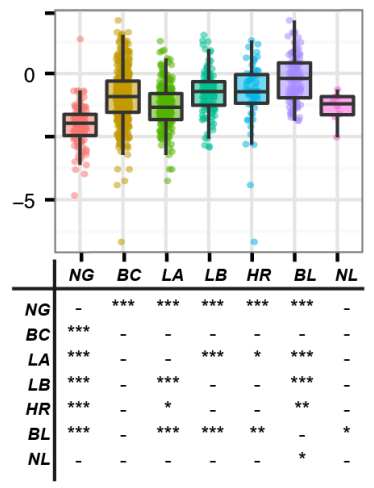

NR2A1

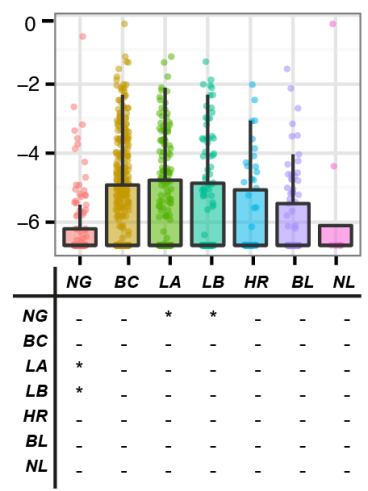

NR2A2

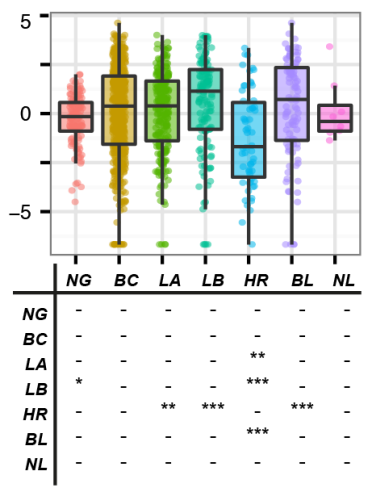

NR3B1

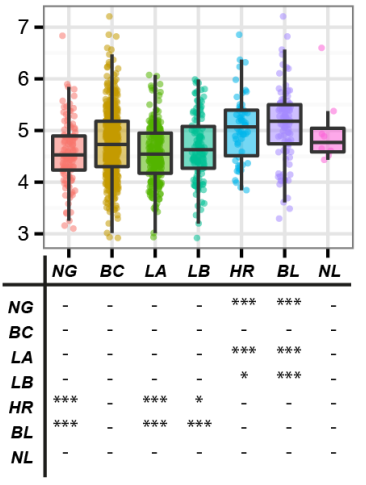

NR3B2

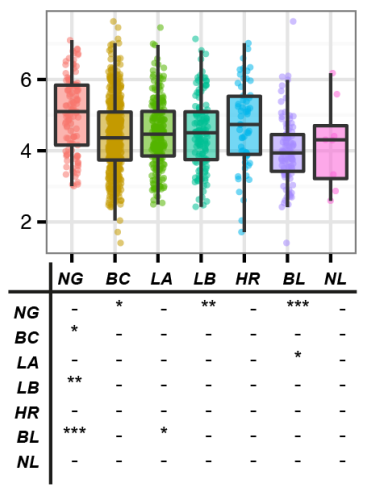

NR3B3

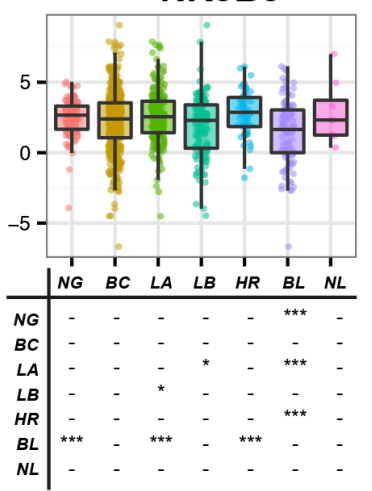

NR5A1

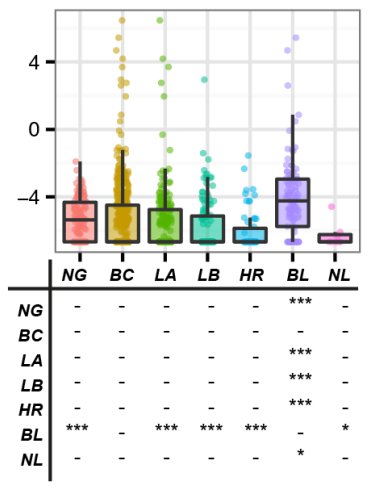

NR5A2

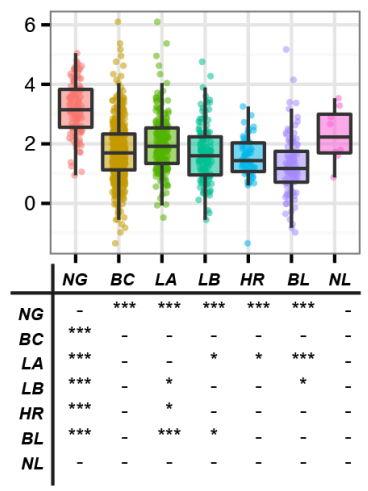

Figure 4: Expression of Enigmatic-Orphan receptors in normal mammary glands and breast-cancer tissue. The boxplots illustrate the expression of the indicated mRNAs belonging to the Enigmatic-Orphans family of nuclear receptors (NRs) in normal mammary-glands $(N G)$, all breast-cancers $(B C)$ and the Luminal-A (LA), Luminal-B (LB), HER2 (HR), Basal (BL) and Normal-like $(N L)$ PAM50 mammary-tumors. Underneath each box-plot, the tables show significant differences in the mRNA expression levels of each NR between the indicated groups. The results were obtained from the data available in the TCGA (The Cancer Genome Atlas; http:// cancergenome.nih.gov). Normalization, quantification and statistical analysis on raw sequencing counts was performed using the Limma/ Voom (http://bioconductor.org) package in R statistical environment. * (adjusted $p<0.01$ ), ** (adjusted $p<0.001$ ), *** (adjusted $p<$ $0.0001)$. 
Table 3: Human orphan receptors

\begin{tabular}{|c|c|c|c|c|c|c|c|c|}
\hline \multicolumn{8}{|c|}{ Orphan-Receptors } & \multirow[b]{2}{*}{$\begin{array}{c}\text { Onco-suppressive } \\
\text { action }\end{array}$} \\
\hline $\begin{array}{l}\text { NROBI (DAX-1) } \\
\text { Dosage-sensitive-sex reversal- } \\
\text { Adrenal-hypoplasia-critical- } \\
\text { region-on-chromosome-X- } \\
\text { gene-I }\end{array}$ & $\mathrm{X}$ & 2 & NP_000466 & 470 & - & $231-464$ & Unknown & \\
\hline $\begin{array}{c}\text { NROB2 }(\mathrm{SHP}) \\
\text { Small-Heterodimeric-Partner }\end{array}$ & 1 & 2 & NP_068804 & 257 & - & $32-254$ & $\begin{array}{l}\text { CD437 (PUBCHEM:135411)(synth.agonist) Farhana L et al, Cancer Res (2007) 67:318- } \\
25\end{array}$ & $\begin{array}{c}\text { Onco-suppressive } \\
\text { action }\end{array}$ \\
\hline $\begin{array}{l}\text { NRIDI (REV-ERB } \alpha) \\
\text { Related-1o-vERBa. }\end{array}$ & 17 & 8 & NP_068370 & 614 & $127-215$ & $418-611$ & $\begin{array}{l}\text { Heme (PUBCHEM:444097)(end.agonist) Raghuram S et al, Nat Struct Mol Biol (2007) } \\
\text { 14:1207-13 } \\
\text { GSK4112 (PUBCHEM:50905018) (synth.agonist) Meng QJ et al, J Cell Science (2008) } \\
\text { 121:3629-35 } \\
\text { SR9009 (PUBCHEM:57394020) (synth.agonist) Solt LA et al, Nature (2012) 485:62-8 }\end{array}$ & $\begin{array}{l}\text { Onco-suppressive } \\
\text { action }\end{array}$ \\
\hline $\begin{array}{c}\text { NRID2 (REV-ERB } \beta) \\
\text { Related-1o-vERBB }\end{array}$ & 3 & 8 & NP_005117 & 579 & $98-186$ & $389-577$ & $\begin{array}{l}\text { Heme (PUBCHEM:444097)(end.agonist) Raghuram S et al, Nat Struct Mol Biol (2007) } \\
\text { 14:1207-13 } \\
\text { SR9009 (PUBCHEM:57394020)(synth.agonist) Solt LA et al, Nature (2012) 485:62-8 } \\
\text { SR8278 (PUBCHEM:53393127)(synth.antagonist) Kojetin D et al, ACS Chem Biol (2011) } \\
\text { 6:131-4 }\end{array}$ & Unknown \\
\hline $\begin{array}{c}\text { NR2Cl (TR2) } \\
\text { Testicular-Receptor-2 }\end{array}$ & 12 & $\begin{array}{l}14 \\
12 \\
12\end{array}$ & $\begin{array}{l}\text { NP_003288 } \\
\text { NP_001120834 } \\
\text { NP_001027458 }\end{array}$ & $\begin{array}{l}603 \\
483 \\
467\end{array}$ & $\begin{array}{l}108-194 \\
108-194 \\
108-194\end{array}$ & $\begin{array}{l}368-589 \\
368-465 \\
368-464\end{array}$ & Unknown & Unknown \\
\hline $\begin{array}{c}\mathrm{NR2C2}(\mathrm{TR} 4) \\
\text { Testicular-Receptor-4 }\end{array}$ & 3 & $\begin{array}{l}14 \\
15\end{array}$ & $\begin{array}{l}\text { NP_001278623 } \\
\text { NP_003289 }\end{array}$ & $\begin{array}{l}596 \\
615 \\
\end{array}$ & $\begin{array}{l}112-198 \\
131-217\end{array}$ & $\begin{array}{l}361-582 \\
380-601\end{array}$ & Unknown & Unknown \\
\hline $\begin{array}{c}\text { NR2E1 (TLX) } \\
\text { Drosophila-Tailless-Homolog }\end{array}$ & 6 & $\begin{array}{l}9 \\
9 \\
\end{array}$ & $\begin{array}{c}\text { NP_003260 } \\
\text { NP } 001273031 \\
\end{array}$ & $\begin{array}{l}385 \\
422 \\
\end{array}$ & $\begin{array}{c}8-99 \\
45136 \\
\end{array}$ & $\begin{array}{l}187-354 \\
191-406 \\
\end{array}$ & Ccrp-1, -2 and -3 (synth. agonists) Benod C et al, PLoS One (2014)9:e99440 & $\begin{array}{l}\text { Oncogenic } \\
\text { Action }\end{array}$ \\
\hline $\begin{array}{c}\text { NR2E3 (PNR) } \\
\text { Photo-specific-Nuclear- } \\
\text { Receptor }\end{array}$ & 15 & $\begin{array}{l}7 \\
8\end{array}$ & $\begin{array}{l}\text { NP_057430 } \\
\text { NP_055064 }\end{array}$ & $\begin{array}{l}367 \\
410\end{array}$ & $\begin{array}{l}39-130 \\
39-130\end{array}$ & $\begin{array}{l}192-367 \\
192-397\end{array}$ & Unknown & $\begin{array}{l}\text { Oncogenic } \\
\text { Actio }\end{array}$ \\
\hline $\begin{array}{l}\text { NR2F1 (COUPTF } 1 \alpha) \\
\text { COUP-Transcription-Factor- } \\
\text { la }\end{array}$ & 5 & 3 & NP_005645 & 423 & $86-158$ & $184-419$ & Unknown & $\begin{array}{c}\text { Onco-suppressive } \\
\text { action }\end{array}$ \\
\hline $\begin{array}{l}\text { NR2F2 (COUPTF } 1 \beta) \\
\text { COUP-Transcription-Factor- } \\
1 \beta\end{array}$ & 15 & $\begin{array}{l}3 \\
3 \\
3\end{array}$ & $\begin{array}{l}\text { NP_066285 } \\
\text { NP_001138628 } \\
\text { NP_001138627 }\end{array}$ & $\begin{array}{l}414 \\
261 \\
281\end{array}$ & $\begin{array}{c}79-151 \\
- \\
-\end{array}$ & $\begin{array}{c}183-414 \\
24-258 \\
44-278\end{array}$ & $\begin{array}{l}\text { Unknown } \\
\text { Pyridaben (PUBCHEM:91754)(synth. antagonist) bindingDB database } \\
\text { (http://www.bindingdb.org) }\end{array}$ & $\begin{array}{c}\text { Onco-suppressive } \\
\text { action }\end{array}$ \\
\hline $\begin{array}{l}\text { NR2F6 (COUPTF-1Y) } \\
\text { COUP-Transcription-Factor- } \\
1 \gamma\end{array}$ & 19 & 4 & NP_005225 & 404 & $56-128$ & $165-400$ & Unknown & $\begin{array}{l}\text { Oncogenic } \\
\text { action }\end{array}$ \\
\hline $\begin{array}{c}\text { NR4A1 (NURR77) } \\
\text { Nuclear-Receptor-Related-77 }\end{array}$ & 12 & $\begin{array}{l}8 \\
8 \\
8\end{array}$ & $\begin{array}{l}\text { NP_001189163 } \\
\text { NP_001189162 } \\
\text { NP_002126 }\end{array}$ & $\begin{array}{l}652 \\
611 \\
598\end{array}$ & $\begin{array}{l}319-393 \\
278-352 \\
264-339 \\
\end{array}$ & $\begin{array}{l}415-652 \\
374-611 \\
409-459 \\
\end{array}$ & Unknown & $\begin{array}{c}\text { Onco-suppressive } \\
\text { action? }\end{array}$ \\
\hline $\begin{array}{c}\text { NR4A2 (NURR1) } \\
\text { Nuclear-Receptor-Related-1 }\end{array}$ & 2 & 8 & NP_006177 & 598 & $260-335$ & $409-459$ & Unknown & Unknown \\
\hline $\begin{array}{c}\text { NR4A3 (NOR1) } \\
\text { Nuclear-Orphan-Receptor-1 }\end{array}$ & 9 & $\begin{array}{l}7 \\
8 \\
5\end{array}$ & $\begin{array}{l}\text { NP_775292 } \\
\text { NP_008912 } \\
\text { NP_775291 }\end{array}$ & $\begin{array}{l}637 \\
626 \\
443\end{array}$ & $\begin{array}{l}301-375 \\
290-364 \\
290-364\end{array}$ & $\begin{array}{l}407-637 \\
396-626\end{array}$ & $\begin{array}{l}\text { PGA2 (PUBCHEM:5280880)(end. agonist) Kagaya S et al, Biol Pharm Bull (2005) } \\
\text { 28:1603-7 } \\
\text { 6-mercaptopurine (PUBCHEM:667490)(synth. agonist) Wansa KD et al, J Biol Chem } \\
\text { (2003) 278:24776-90 }\end{array}$ & $\begin{array}{c}\text { Onco-suppressive } \\
\text { action }\end{array}$ \\
\hline $\begin{array}{c}\text { NR6AI (GCNF) } \\
\text { Germ-Cell-Nuclear-Facior }\end{array}$ & 9 & $\begin{array}{l}10 \\
10\end{array}$ & $\begin{array}{l}\text { NP_201591 } \\
\text { NP_001480 }\end{array}$ & $\begin{array}{l}480 \\
475\end{array}$ & $\begin{array}{l}52-141 \\
48-137 \\
\end{array}$ & $\begin{array}{l}256-467 \\
251-462\end{array}$ & Unknown & $\begin{array}{l}\text { Oncogenic } \\
\text { Action }\end{array}$ \\
\hline
\end{tabular}

The table contains basic information on the characteristics of the Orphan-Receptors group of nuclear receptors (NRs). The first column lists the human NRs considered in the review article. The official symbol of each NR is indicated in italics, while the original alias of each protein product is indicated in parenthesis. The full name of each NR is indicated underneath in italics. The second column from the left lists the human chromosome (Chr) each NR maps to. The number of exons encoding the transcripts giving rise to the corresponding NR protein-variant is indicated in the third column. The fourth column lists the accession number of each NR protein-variant. The amino acid (aa) length of each NR protein variant, the position of the DNA-binding domain (DBD) and the ligand-binding domain (LBD) are indicated in columns five, six and seven, respectively. Column eight contains a list of representative endogenous (end.) and synthetic (synth.) agonists, antagonists and reverse agonists for each NR along with an appropriate reference. The chemical structures of the listed molecules can be found in the PUBCHEM database with the use of the PUBCHEM-CID accession numbers provided. The PBCHEM chemical structure is not available in the case of the NR2E1 agonists Ccrp-1, -2 and -3. When possible, the predicted onco-suppressive (bold) or oncogenic (black-boxed) action of the corresponding NR is indicated in the last column on the right. Synthetic agonists and antagonists of potential therapeutic interest targeting onco-suppressive and oncogenic NRs, respectively, are marked in bold and boxed in black. Finally, in the few cases where supportive data are available, the type of breast-cancer which is predicted to represent a preferential target of the NR is listed in the last column.

acid, induces apoptosis in $\mathrm{ER}^{+} /$and $\mathrm{ER} /$ breast-cancer cells and this effect is potentiated by RXR-selective ligands [9]. NR1C1 onco-suppressive action may involve breastcancer stromal components. Indeed, NR1C1-activation in mammary-tumor cells suppresses Hypoxia-InducibleFactor-1- $\alpha$ signaling, reduces Vascular-EndothelialGrowth-Factor secretion and tube formation by endothelial cells, suggesting anti-angiogenic effects [10]. NR1C1 anti-tumor activity may be of particular relevance in $\mathrm{ER}^{+}$/breast-cancer, since anti-estrogens induce NR1C1mRNA in $\mathrm{ER}^{+} / M C F-7$ cells and $\mathrm{ER} \alpha$ over-expression into ER- $/ M D A-M B-231$ cells decreases NR1C1-mRNA [11].

In $\mathrm{ER}^{+} / M C F-7$ and $\mathrm{ER}^{+} / T 47 D$ breast-cancer cells, NR1C2-activation by GW501516 stimulates proliferation and angiogenic responses [10]. In addition, the NR1C2antagonist, SR13904, inhibits cell-growth and -survival [12]. Two NR1C2-inverse-agonists (ST247 = methyl 3-(N-(4-(hexylamino)-2-methoxyphenyl)sulfamoyl)

thiophene-2-carboxylate and DG172 = (Z)-2-(2bromophenyl)-3-(4-(4-methylpiperazin-1-yl)phenyl) acrylonitrile dihydrochloride) inhibit serum- and TGF $\beta$ induced invasion of ER-/MDA-MB231 cells into threedimensional matrixes, suggesting that NR1C2 favors tumor-cell dissemination [13]. A role in ST247/DG172 action is played by Angiopoietin-Like-4 down-regulation. NR1C2 oncogenic action is supported by data obtained in $M M T V-P P A R \beta / \delta$ transgenic-models of mammary carcinogenesis where the NR1C2-agonist, GW501516, 
reduces tumor latency [14]. Further support comes from transgenic-mice over-expressing 3-PhosphoinositideDependent-Kinase-1, a protein regulated by NR1C2, where GW501516 accelerates tumorigenesis [15]. NR1C2 oncogenic action may involve the EGFR/ERBB2 pathway via FABP5 (Fatty-Acid-Binding-Protein-5), which delivers ligands to NR1C2. In $\mathrm{ER}^{+} / M C F-7$ cells, EGFR/ERBB2-dependent proliferative responses are accompanied by FABP5 induction [16]. In MMTV-ErbB2/ HER2 mice, spontaneously developing breast-cancer, FABP5 ablation relieves activation of EGFR downstream signals, down-regulates NR1C2 target-genes involved in cell-proliferation and suppresses tumor-growth [17]. The retinoid pathway may also be involved in NR1C2 oncogenic activity, as NR1C2 is bound/activated by ATRA [18]. Indeed, ATRA delivery to NR1C2 and RARs is dependent on FABP5 and CRABP-II, respectively. In ATRA-resistant MMTV-neu transgenic-model of breastcancer, decreasing FABP5/CRABP-II ratio diverts ATRA from NR1C2 to RAR and suppresses tumor-growth [19]. Although all this is consistent with an oncogenic action of NR1C2 in breast-cancer, there is also evidence to the contrary. The NR1C2-agonist, GW501516, inhibits $M C F$ 7 cells growth [20] and NR1C2 over-expression/activation reduces clonogenicity and in-vivo growth of $\mathrm{ER}^{+} / M C F$ 7 and $\mathrm{ER}^{-} / M D A-M B 231$ cells [21]. In conclusion, the majority of the available data indicates that NR1C2 is prooncogenic in breast-carcinoma [22].

NR1C3 levels are associated with improved clinical outcome and represent a prognostic factor for overall-survival in $\mathrm{ER}^{+} /$breast-cancer patients, suggesting onco-suppressive properties [23]. The synthetic NR1C3agonists, thiazolidinediones, suppress mammary-tumor growth in-vitro and in-vivo [24-26]. Thiazolidinedioneactivated NR1C3 interferes with ER $\alpha$, Signal-Transducerand-Activator-of-Transcription-5B and Nucler-FactorkappaB, inhibiting the proliferation of $\mathrm{ER}^{+} /$and $\mathrm{ER}$-/cells which undergo differentiation [27] and apoptosis [28]. In addition, thiazolidinediones inhibit TGF $\beta$ signaling, which suppresses breast-cancer early-development [25]. Finally, NR1C3-agonists reduce mammary-tumor angiogenesis and invasion [29]. In rats, the NR1C3ligand, GW7845, inhibits carcinogen-induced breastcancer [26]. Troglitazone prevents 7,12-dimethylbenz(a) anthracene-induced transformation of murine breast-tissue [30] and NR1C3 heterozygous-deletion causes greater susceptibility to mammary-tumor development after exposure to the same anthracene-related compound [31]. The action of NR1C3 stimulation is not limited to breastcancer prevention and extends to treatment [32]. The only exception to the in-vivo data supporting NR1C3 oncosuppressive properties is represented by a study showing that the NR acts as a tumor-promoter in a transgenicmodel of breast carcinogenesis via interference with the WNT-pathway [33]. A small-sized clinical-trial reports that patients with metastatic breast-cancer fail to show any benefit from troglitazone administration [34]. An equally small and recent trial demonstrates that administration of rosiglitazone between the time of diagnostic biopsy and definitive surgery is well-tolerated although it does not alter breast-cancer cell-proliferation [35].

\section{NR1H2 (LXRß:liver-X-receptor- $\beta$ ) and NR1H3 (LXR $\alpha$ :liver-X-receptor- $\alpha$ )}

NR1H2 and NR1H3 are involved in the metabolism/ homeostasis of cholesterol/lipids/bile-acids/steroidhormones and modulate innate immunity [36]. NR1H2 and NR1H3 are activated by oxysterols, like 27-hydroxycholesterol (Table 1). There is cross-talk between NR1H2/ NR1H3 and NR1H4/NR1F1, as NR1H4 activation downregulates NR1H3, while NR1H3 and NR1F1 antagonize each other in terms of transcriptional activity [36, 37]. NR1H2 (UNIGENE-Hs.432976) and NR1H3 (UNIGENEHs.438863) mRNA expression is ubiquitous. The largest amounts of NR1H3 mRNA are observed in adipose-tissue. According to the TCGA dataset, normal mammary-glands contain high NR1H2 and NR1H3 mRNA levels (Figure 3). No difference in NR1H2 expression is observed among the PAM50 groups of breast-cancer and normal tissue. By contrast, NR1H3 is down-regulated in all PAM50 tumor groups relative to the normal mammary-gland.

As for the potential role of NR1H2 and NR1H3 in breast-cancer, little and contrasting evidence is available. NR1H2/NR1H3 ligands secreted by tumor cells inhibit CCR7 expression on maturing dendritic cells, impairing immune-surveillance and favoring tumor growth [38]. In mouse breast-cancer models, 27-hydroxycholesterol augments ER-dependent mammary-tumor growth and increases NR1H2/NR1H3-dependent metastasis [39]. The two effects require conversion of cholesterol into 27-hydroxycholesterol by CYP27A1 [40]. The data obtained in these mouse models contrast with the observations made in some breast-cancer cells, where NR1H2/NR1H3 activation reduces proliferation with down-regulation of genes involved in cell cycle progression, DNA replication and other cell-growthrelated processes $[41,42]$. In $\mathrm{ER}^{+} /$breast-tumors the NR1H2/NR1H3 growth-inhibitory action may result from systemic effects, as the two NRs control hepatic estrogen biosynthesis. In the liver, NR1H2/NR1H3 stimulation results in sulfotransferase (an enzyme critical for estrogen deactivation) induction which inhibits breast-cancer growth in xenografted mice [43]. Non-cell autonomous growth-inhibitory effects are also suggested by in-vitro results, as culture medium from NR1H2/NR1H3 activated macrophages causes growth-inhibition and apoptosis of breast-cancer cells [44].

In conclusion, NR1H2/NR1H3 activation may represent a strategy for the treatment/chemoprevention of breast-cancer, although caution should be exercised, since 
NR1H2/NR1H3-agonists may favor the metastatic spread of tumor cells [39].

\section{NR1H4 (FXR:farnesoid-X-receptor)}

NR1H4 transcriptional activity is stimulated by bileacids, such as chenodeoxycholic acid $[45,46]$. Adrenalglands, kidney, liver and intestine express the highest NR1H4-mRNA levels (UNIGENE-Hs.282735), although the transcript is present also in mammary-glands. With the exception of the Normal-like group, all PAM50 mammarytumor sub-types express smaller NR1H4 amounts than the normal counterpart (Figure 3). In breast-cancer, NR1H4protein levels are associated with ER-status and luminal markers [47].

Data on the role played by NR1H4 in mammarytumors are contrasting. As bile-acids are a risk factor for post-menopausal breast-cancer [48], their high concentrations in breast-cysts/plasma of mammarytumor patients [49] suggest a role for NR1H4 in disease induction/progression. Consistent with this hypothesis, the NR1H4 agonist, deoxycholate, promotes survival and favors migration of ER- $/ M D A-M B-231$ cells, while the inverse-agonist, guggulsterone, exerts opposite effects [50]. Similarly, farnesol, another NR1H4-agonist, exerts mitogenic effects in $\mathrm{ER}^{+} / M C F-7$ cells, but not in $\mathrm{ER}^{-} / M D A-M B 231$ cells [47]. Mitogenesis may require binding/activation of ER $\alpha$ by NR1H4 [47]. NR1H4dependent proliferation of $\mathrm{ER}^{+} /$breast-cancer cells is stimulated by estrogen deprivation, which recapitulates menopause and aromatase-inhibitor treatment [47]. In spite of the evidence indicating that NR1H4 is oncogenic, particularly in $\mathrm{ER}^{+} /$breast-cancer, there is also evidence supporting the idea that NR1H4-activation is antioncogenic. High concentrations of the GW4064 agonist induce apoptosis of $\mathrm{ER}^{+} / M C F-7$ and $\mathrm{ER}^{-} / M D A-M B 468$ cells [51]. Chenodeoxycholic-acid and GW4064 inhibit growth of tamoxifen-resistant $\mathrm{ER}^{+} /$cells. Interestingly, chenodeoxycholic-acid reduces EGF-induced growth of these cells via inhibition of the HER2 pathway [52]. On the basis of these data, it is currently difficult to establish whether NR1H4 is endowed with oncogenic or onco-suppressive properties in breast cancer and whether targeted therapeutic strategies should be aimed at inhibiting or activating the receptor.

\section{NR1I2 (PXR:pregnane-X-receptor)}

NR1I2 plays a role in xenobiotic metabolism and is activated by various synthetic ligands (Table 1) [53]. NR1I2 regulates the expression of genes involved in xenobiotic metabolism and transport [54]. NR1I2mRNA highest levels are observed in liver although considerable amounts are measurable also in mammaryglands (UNIGENE-Hs.7303). Relative to normal tissue,
NR1I2-mRNA is down-regulated in Her2 tumors, while the opposite is true in Basal tumors (Figure 3). The TCGA data on the expression of the NR1I2 transcript in the PAM50 breast cancer subtypes are only partially in line with the reported inverse relationship between NR1I2-mRNA expression and ER-positivity [55]. NR1I2 represents a negative prognostic marker in breast-cancer, as NR1I2-protein levels correlate with labeling-index, histologic-grade and lymph-node-status [56]. In addition, NR1I2-protein over-expression and nuclear localization is associated with infiltrative-carcinoma recurrence [56]. NR1I2 plays a role in breast-cancer cell resistance to antitumor agents. In $\mathrm{ER}^{+} / M C F-7$ cells, NR1I2 is involved in induced resistance to tamoxifene via up-regulation of Multidrug-Resistance-Associated-protein-2, a membranetransporter controlling drug efflux [57]. In $\mathrm{ER}^{+} / M C F-7$ and $E R^{-} / M D A-M B 231$ cells, SR12813 causes docetaxel resistance and induction of the drug-resistance genes, Multidrug-Resistance-1 and Breast-cancer-ResistanceProtein $B$ [58]. Thus, NR1I2-inhibition should be considered in the treatment of tumors with acquired resistance to anti-hormones and chemotherapy.

\section{ENIGMATIC-ORPHANS}

The family of Enigmatic-orphans contains NRs whose endogenous ligands are ill-defined or unknown and consists of eleven members.

\section{NR1F1 (ROR $\alpha$ :RAR-related-orphan-receptor- $\alpha$ ), NR1F2 (RORß:RAR-related-orphan-receptor- $\beta$ ) and NR1F3 (ROR:RAR-related-orphan- receptor- $\gamma$ )}

NR1F1, NR1F2 and NR1F3 control circadian rhythms [59]. NR1F2 plays also a role in lineage specification of $\mathrm{CD}^{+}$T-helper into Th17 cells [60]. NR1F1, NR1F2 and NRF3 bind to the regulatory regions of target-genes (ROR-Response-Elements) as monomers [61]. ATRA and melatonin are endogenous NR1F1-agonists, while 7ß,27-dihydroxycholesterol is an endogenous NR1F3-ligand (Table 3). Only synthetic agonists/antagonists targeting NR1F1 and NR1F3 are available. The highest NR1F1-mRNA levels are observed in skin, muscle and adrenal-glands (UNIGENEHs.560343), while NR1F2-mRNA expression is restricted to eyes and adrenal-glands (UNIGENE-Hs.494178) and NR1F3-mRNA is ubiquitous (UNIGENE-Hs.256022). NR1F1 and NR1F3 are expressed in the mammarygland, while NRF2 is under-represented in the organ. All PAM50-classified breast-cancer types express lower NR1F1-mRNA levels than the normal tissue (Figure 4). Luminal-A and Normal-like tumors presents with the largest NR1F1 amounts. Similarly, NR1F2 is downregulated in most cancer subgroups relative to the normal 
tissue. Basal tumors are the poorest NR1F2 source. Unlike NR1F1 and NR1F2, larger NR1F3-mRNA amounts are present in mammary-tumors than in normal glands.

NR1F1 is a growth stimulator in $\mathrm{ER}^{+} /$cells, while it is an inhibitor in ER-/cells [62]. NR1F1 may stimulate $\mathrm{ER}^{+} /$cell-growth via $\mathrm{ER} \alpha$ binding/activation or aromatase induction [63]. Besides inhibiting growth, NR1F1 exerts anti-invasive actions in ER/cells and tumors [64-66]. In ER $\%$ cells and xenografts, transcriptional Semaphorin$3 F$ induction via a ROR-Response-Element contributes to NR1F1 anti-invasive and growth-inhibitory activities [64]. In addition, NR1F1 binds E2F1-transcriptionfactor, inhibits E2Fl-acetylation and transcriptional activity, reducing ductal epithelial-cell proliferation [66]. No studies on NR1F2 in breast-cancer are available and the number of publications involving NR1F3 is limited $[64,67,68]$. High NR1F3 expression is associated with an increase in metastasis-free survival [67]. It is also possible that NR1F3 expression enhances mammarytumors aggressiveness reducing T-lymphocytes immunesurveillance [64]. In conclusion, NRF1 induction/ activation and NRF13 suppression/inhibition may be of therapeutic use, particularly in ER//breast-cancer

\section{NR1I3 (CAR:constitutive-androstane-receptor)}

NR1I3 is characterized by a large number of protein variants (Table 2). NR1I3 high basal activity is inhibited by steroids related to androstenol [69] and is involved in drug-metabolism and energy-homeostasis [70]. NR1I3 and NR1I2 control an overlapping set of genes and their physiological function seems to be redundant, although NR1I3 plays a unique role in bilirubin clearance [71]. NR1I3 is activated by 4-bis[2(3,5-dichloropyridyloxy)]benzene (TCPOBOP) directly or indirectly by phenobarbital via cytoplasm-to-nucleus translocation [72]. The only known synthetic NR1I3agonist is (4-chlorophenyl)imidazo[2,1-b][1,3]thiazole5-carbaldehyde-O-(3,4-dichlorobenzyl)oxime (CITCO), while various synthetic NR1I3-inhibitors are available. NR1I3-mRNA expression is limited to liver and kidney (UNIGENE-Hs.349642) and very low NR1I3-mRNA levels are detectable in the mammary-gland. NR1I3 is upregulated in all mammary-tumor sub-types, with the sole exception of Normal-like cancer (Figure 4). There are no studies on NR1I3 in breast cancer indicating whether it could be oncogenic or not.

\section{NR2A1(HNF4 $\alpha$ :hepatocyte-nuclear-factor-4 $\alpha$ ) and NR2A2 (HNF4 $\gamma:$ hepatocyte-nuclear-factor-4)}

NR2A1 binds as a homodimer to target genes [73] and its transcriptional activity may be regulated by endogenous ligands such as linoleic acid [74]. NR2A2 interacts with the same DNA target-sites recognized by
NR2A1 [75] and it is bound/activated by endogenous fatty-acids, which are difficult to replace with synthetic molecules [76]. NR2A1-mRNA expression is restricted to liver, kidney, small intestine and stomach (UNIGENEHs.116462), while NR2A2-mRNA is present in kidney, stomach and muscle (UNIGENE-Hs.241529). Very small NR2A1 and NR2A2 mRNA amounts are detectable in mammary-glands. NR2A1 levels are slightly higher in Luminal-A and Luminal-B cancers relative to normal tissue (Figure 4). Her2 tumors contain the smallest NR2A2 amounts. In mammary-glands, NR2A1 has been the object of few studies [77-81], while no studies on NR2A2 are available. NR2A1 may have oncosuppressive properties [77], as it is down-regulated in mammary epithelial-cells undergoing epithelial-to-mesenchymal transition (EMT).

\section{NR3B1 (ERR $\alpha:$ estrogen-related-receptor- $\alpha$ ), NR3B2 (ERRß: estrogen-related-receptor- $\beta$ ) and NR3B3 (ERR $\gamma$ :estrogen-related-receptor- $\gamma$ )}

NR3B1, NR1B2 and NRB3 show structural similarity with ERs [82]. Diethylstilbestrol is a nonselective endogenous NR3B-agonist (Table 2). NR3Bs bind to ERRE (Estrogen-Related-Response-Elements) in target-genes. Although it was originally thought that NR3Bs and ER $\alpha$ control common target-genes, a recent study demonstrates that NR3B1 and ER $\alpha$ share only a minor fraction of targets [83]. NR3B1-mRNA (UNIGENE-Hs.110849) and NRB3-mRNA (UNIGENEHs.444225) are ubiquitously expressed, while NRB2mRNA expression is restricted (eye and muscle; UNIGENE-Hs.435845). NR3B1 regulates circadianclocks, influencing metabolic homeostasis and locomotoractivity [84-86].

In mammary-glands, NR3B1 and NR3B2 are highly expressed, while NR3B3 levels are negligible (Figure 4). Normal tissues and all PAM50-classified breastcancers express similar amounts of NR3B2-mRNA and NR3B3-mRNA. By converse, HER2-like and Basal-like mammary-tumors contain larger NR3B1-mRNA amounts than the normal tissue, which is consistent with a positive correlation between NR3B1 and HER2 expression [87]. In line with this, HER2/MAPK/AKT activation causes NR3B1 phosphorylation/activation in HER2 ${ }^{+} / B T 474$ cells [88]. In addition, NR3B1 activates transcription of the genes contained in the ERBB2 amplicon observed in the majority of HER2 ${ }^{+}$breast tumors, possibly explaining the delay in tumor development observed following $N R 3 b 1$ knock-out in a mouse model of ERBB2-initiated mammary cancerogenesis [89]. NR3B1 is a negative prognostic factor for breast-tumors, being associated with increased recurrence-risk and adverse clinical-outcome [90]. Consistent with NR3B1 oncogenic action, NR3B1antagonists reduce the size of $\mathrm{ER}^{+} /$and $\mathrm{ER}^{-} / \mathrm{xenografts}$ [91], while NR3B1 knock-down diminishes in-vitro 


\section{Orphan-Receptors}
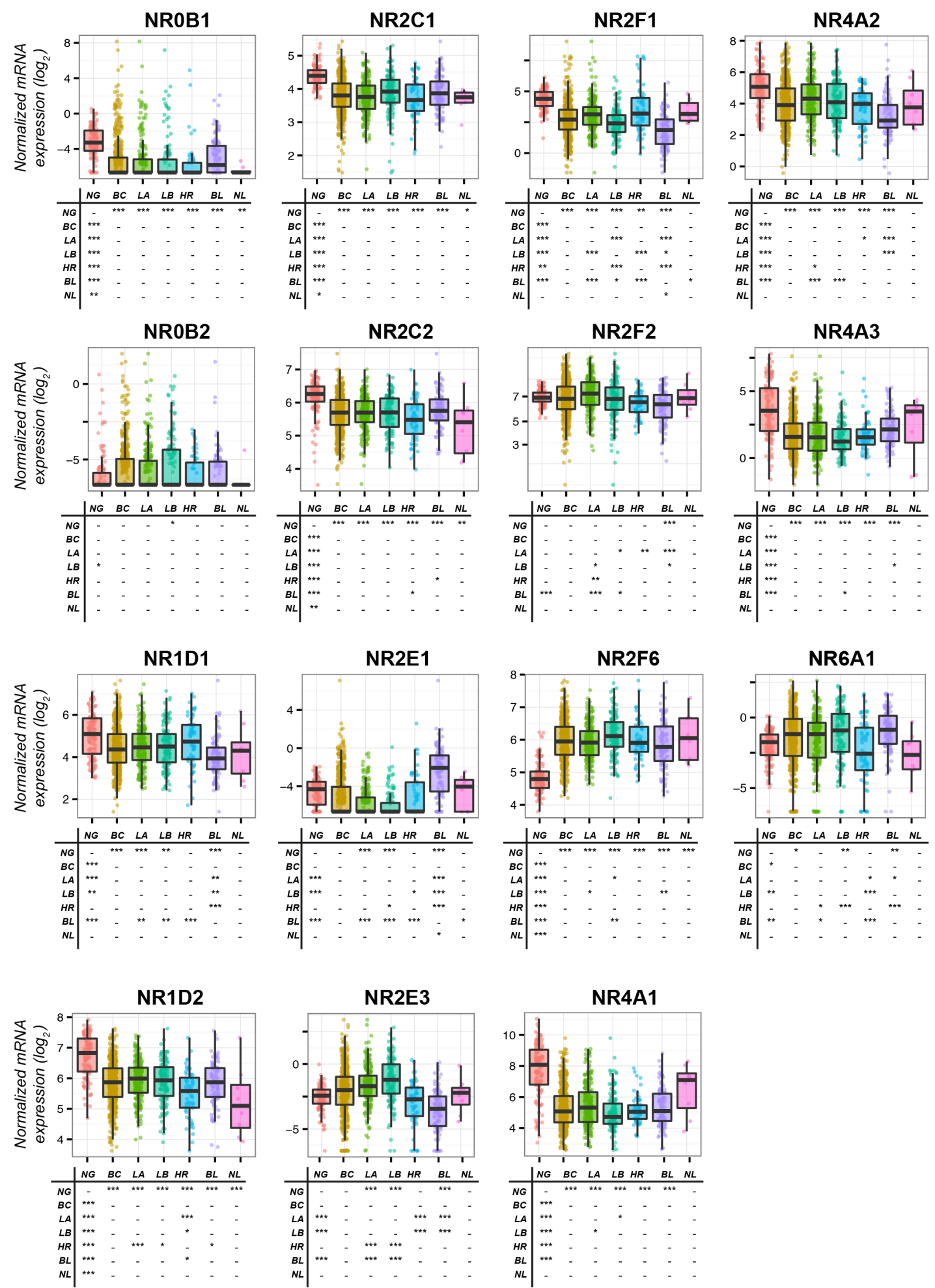

Figure 5: Expression of Orphan-Receptors in normal mammary glands and breast-cancer tissue. The box-plots illustrate the expression of the indicated mRNAs belonging to the Orphan-Receptors family of nuclear receptors (NRs) in normal mammaryglands $(N G)$, all breast-cancers $(B C)$ and the Luminal-A $(L A)$, Luminal-B $(L B)$, HER2 (HR), Basal (BL) and Normal-like (NL) PAM50 mammary-tumors. Underneath each box-plot, the tables show significant differences in the mRNA expression levels of each NR between the indicated groups. The results were obtained from the data available in the TCGA (The-Cancer-Genome-Atlas: http://cancergenome. nih.gov). Normalization, quantification and statistical analysis on raw sequencing counts was performed using the Limma/Voom (http:// bioconductor.org) package in R statistical environment. * (adjusted $p<0.01), * *$ (adjusted $p<0.001),{ }^{* * *}($ adjusted $p<0.0001)$. 
migration and in-vivo growth of ER-/MDA-MB-231 cells [91]. The pathways underlying NR3B1 pro-oncogenic action are obscure and may vary in $\mathrm{ER}^{+} /$and $\mathrm{HER} 2^{+}$/ tumors. WNT inhibitors suppress NR3B1 transcriptional activity via $\beta$-catenin [92], reducing breast-cancer cells migration. In contrast, NR3B1-activation stimulates Vascular-Endothelial-Growth-Factor production and angiogenesis [93]. In $\mathrm{ER}^{+} /$breast-cancer cells, NR3B1 increases estrogen synthesis via aromatase induction [94]. As local synthesis of estrogens is fundamental for the growth of post-menopausal $\mathrm{ER}^{+} /$breast-cancer, NR3B1 inhibition may represent a therapeutic strategy in these patients. In breast-cancer, single study indicates that NR3B2 is a potential tumor-suppressor [95], while the potential tumor-suppressive activity of NR3B3 is supported by more studies $[82,96,97]$. NR3B3suppresses breast tumor growth and reverses the process of epithelialto-mesenchymal transition [97].

In summary, while NR3B1 suppression/inhibition is likely to be of therapeutic value in Her2, Basal and postmenopausal or tamoxifen resistant $E R^{+} /$tumors, activation or induction of NR3B3 may represent a viable therapeutic strategy in $E R^{-/}$tumors.

\section{NR5A1 (SF-1:steroidogenic-factor-1) and NR5A2 (LRH-1:liver-receptor-homolog-1)}

NR5A1 controls the expression of genes involved in cortisol/corticosterone biosynthesis [98], while NR5A2 play a role in hepatic bile-acids-metabolism, cholesterol-transport and glucose-homeostasis [99]. It is still unresolved whether NR5A1 is activated by endogenous ligands, as its transcriptional activity is stimulated by phosphorylation and by interactions with other proteins [98]. Nevertheless, NR5A1 and NR5A2 bind phospholipids, like phosphatidic-acid and phosphatidyl-choline. In addition, synthetic NR5A1/ NR5A2 agonists/antagonists are available (Table 2). Large NR5A-mRNA amounts are expressed in adrenal-glands and testis (UNIGENE-Hs.495108), while the richest sources of NR5A2 are pancreas, adrenal-glands and liver (UNIGENE-Hs.33446).

In normal mammary-glands, NR5A2 levels are much higher than NR5A1 levels. Basal cancer overexpresses NR5A1 relative to the other tumor subtypes and normal tissue. In contrast NR5A2-mRNA is downregulated in all breast-tumors, regardless of the PAM50 classification (Figure 4). The strongest NR5A2-mRNA expression is observed in Luminal-A Luminal-B and Normal-like which may be consistent with NR5A2-gene control by $\mathrm{ER} \alpha$ [99-101].

NR5A1 has never been the object of studies in breast-cancer while data on NR5A2 are available. NR5A2 knock-down inhibits estrogens proliferative action in $\mathrm{ER}^{+} / M C F-7$ cells and down-regulates $\mathrm{ER} \alpha$ target-genes
[99]. In $\mathrm{ER}^{+}$/ and ER-/breast-cancer cells, NR5A2 is a mitogen and this action may involve NR5A2-dependent stimulation of Growth-Regulation-by-Estrogen-in-Breastcancer-1 (GREB-1) transcription [102]. In ER $\mathrm{ER}^{+} / M C F-7$ and $\mathrm{ER}^{-} / M D A-M B 231$ cells, NR5A2 increases motility, a key process in metastatic spread [103]. Finally, NR5A2 may represent a negative prognostic marker, as a targetgenes signature is associated with poor outcome in highgrade mammary-tumors [104]. Thus, NR5A2 is likely to be an oncogene and reduction of NR5A2-antagonists may produce anti-tumor effects.

\section{ORPHAN RECEPTORS}

The fifteen members of the Orphan-receptors family are NRs for which endogenous-ligands are not identified. The sole exceptions are represented by NR1D1, NR1D2 and NR4A3 for which two endogenous-agonists are hypothesized.

\section{NR0B1(DAX-1:dosage-sensitive-sex-reversal- adrenal-hypoplasia-critical-region-on- chromosome-X-gene-1) and NR0B2 (SHP:small- heterodimeric-partner)}

NR0B1 and NR0B2 are devoid of DNA-binding domains and act as co-repressor/co-activator of NR1Bs/ RARs, NR2Bs/RXRs, NR1Cs, NR1Hs and NR1H4 [105, 106]. NR0B1 plays a role in adrenal-cortex development and puberty onset, while NR0B2 controls various aspects of cell metabolism. NR0B1 expression is restricted to adrenal-glands, lung and pancreas (UNIGENEHs.268490), while NR0B2 mRNA is measurable in liver, stomach, heart, lung and intestine (UNIGENEHs.427055). Mammary-glands contain low NR0B1mRNA and NR0B2-mRNA levels and NR0B1-mRNA is down-regulated in all PAM50 breast-cancer types (Figure 5). NR0B1 is associated with $\mathrm{ER} \alpha, \mathrm{PR}$ and $\mathrm{AR}$ expression [107] and is a positive prognostic factor in node-negative breast-cancer, being correlated with smaller tumor-size, earlier disease-stage and increased survival [106, 107]. NR0B1 is induced by AR-activation in $\mathrm{ER}^{+} / M C F-7$ breastcancer cells and this causes aromatase down-regulation. The effect may underlay AR-ligands anti-estrogenic action. NR0B1 over-expression induces growth-inhibitory and apoptotic responses in $M C F-7$ cells [108]. NR0B2 activation by CD437 exerts pro-apoptotic actions in ER-/ $M D A-M B-468$ breast-cancer cells via transcriptional mechanisms [109]. However, NR0B2 triggers apoptosis also via BCL-2 binding in mitochondria [109]. In conclusion, NR0B1 and NR0B2 are endowed with oncosuppressive properties in breast-cancer. 


\section{NR1D1 (REV-ERB $\alpha$ :related-to-vERB $\alpha$ ) and NR1D2 (REV-ERBß:related-to-vERBß)}

NR1D1 and NR1D2 control circadian-rhythms and regulate fat deposition $[110,111]$. Heme seems to be the endogenous NR1D1/NR1D2 ligand. High NR1D1-mRNA (UNIGENE-Hs.592130) and NR1D2-mRNA (UNIGENEHs.37288) levels are observed in many tissues. NR1D1and NR1D2-mRNAs are down-regulated in neoplastic relative to the normal mammary tissues (Figure 5). Basal tumors are characterized by lower NR1D1 contents than Luminal-A, Luminal-B or Her 2 breast-cancers. Interestingly, the NR1D1-gene maps close to the ERBB2gene and is often amplified in HER $2^{+}$tumors [112]. As for NR1D2 mRNA, the lowest levels are observed in Normallike tumors. While no studies on NR1D2 in mammarytumors are available, NR1D1 may exert onco-suppressive effects, as silencing causes reduced growth/apoptosis of HER2 ${ }^{+} / B T-474$ and $\mathrm{ER}^{+} / M C F-7$ cells [112].

\section{NR2C1 (TR2:testicular-receptor-2) and NR2C2 (TR4:testicular-receptor-4)}

$\mathrm{NR} 2 \mathrm{C} 1$ and NR2C2 can form heterodimers and act as transcriptional activators/repressors of other NRs. $\mathrm{NR} 2 \mathrm{C} 1$ and NR2C2 are involved in early embryonic development and embryonic stem cells [113]. NR2C1mRNA (UNIGENE-Hs.108301) and NR2C2-mRNA (UNIGENE-Hs.555973) are expressed ubiquitously and are measurable in mammary-glands. NR2C1 and NR2C2 levels are lower in breast-cancer than normal tissue (Figure 5). NR2C1 is over-expressed in Basal relative to Her2 and Normal-like tumors. In $\mathrm{ER}^{+} /$breast-cancer cells, NR2C1 suppresses ER $\alpha$-mediated transcriptional activity, blocking ER $\alpha$-binding to DNA via formation of an ER $\alpha-\mathrm{NR} 2 \mathrm{C} 1$ heterodimer. This inhibits estrogeninduced cell-growth and G(1)/S transition [114]. NR2C1 may indirectly contribute to ATRA anti-estrogenic activity in $\mathrm{ER}^{+} /$breast-cancer, as the retinoid controls the activity of this NR in other cellular contexts $[115,116]$. NR2C1 suppresses androgen-mediated AR transactivation, which may be of therapeutic interest in $\mathrm{AR}^{+}$/mammary-tumors [117]. The few available data do not provide clues as to the relevance of $\mathrm{NR} 2 \mathrm{C} 1$ and $\mathrm{NR} 2 \mathrm{C} 2$ in breast-cancer, but it can be suggested that the two receptors are anti-oncogenic.

\section{NR2E1 (TLX:drosophila-tailless-homolog) and NR2E3 (PNR:photo-specific-nuclear-receptor)}

NR2E1 plays a role in neuronal stem-cells homeostasis [118], while NR2E3 is involved in retinal visual function [119]. NR2E1-mRNA (UNIGENEHs.157688) and NR2E3-mRNA (UNIGENE-Hs.187354) expression is restricted to eye and brain and eye and muscle, respectively. Low levels of NR2E1-mRNA and NR2E3-mRNA are detectable in mammaryglands and NR2E1 is further down-regulated in breastcancers (Figure 5). Higher NR2E1 expression levels are observed in Basal relative to Luminal tumors, while the opposite is true for NR2E3. Limited functional data on NR2E1 and NR2E3 are available and only few pertain to the breast-cancer realm. NR2E1 represses target-gene expression in neuronal-stem-cells [118], is an oncogene in glioblastoma and inhibits senescence in different cell types [120]. A recent and seminal paper by Lin et al. [121] supports the idea that NR2E1 is a potential drug target for the treatment of ER- breast cancer. In fact high levels of NR2E1 expression in ER' are a negative prognostic factor in this type of cancer. Consistent with this targeted knock-down of NR2E1 inhibits the growth of different ER- breast cancer cell lines. By converse, overexpression of the nuclear receptor stimulates the formation of mammospheres, the growth and the invasive behavior of ER- $M D A-M B 231$ cells [121]. NR2E3 is an ER $\alpha$ transcriptional activator [122] and it may contribute to hormone-dependent growth of $\mathrm{ER}^{+} /$tumors, although high NR2E3 levels are associated with favorable responses to tamoxifen. NR2E3 oncogenic action may extend to ER $/$ tumors, inducing $M D A-M B-231$ cell migration in-vitro and metastatic spread in-vivo [122].

\section{NR2F1 (COUP-TF $\alpha$ :COUP-transcription-factor-

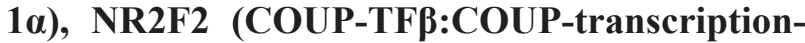 factor-1 $\beta$ ) and NR2F6 (COUP-TFy:COUP- transcription-factor-1 $\gamma$ )}

NR2F1, NR2F2 and NR2F6 control embryonic development. Two NR2F2-protein variants are devoid of a DNA-binding domain (Table 3). The binding $D B$ database (http://www.bindingdb.org) contain several potential NR2F2-ligands, such as pyridaben. NR2F1-mRNA (UNIGENE- Hs.519445), NR2F2-mRNA (UNIGENEHs.347991) and NR2F6-mRNA (UNIGENE- Hs.519445) are expressed ubiquitously. Relative to the normal gland, mammary-tumors contain smaller and equal amounts of NR2F1 and NR2F2, respectively. Basal-like tumors express the lowest levels of both NR2F1 and NR2F2. Relative to the normal gland, NR2F6 is over-expressed in all PAM50-classified breast-cancer sub-types (Figure 5).

NR2F1 enhances ER $\alpha$ transcriptional activity increasing ERK-2 dependent phosphorylation [123].

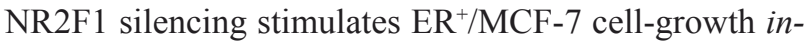
vivo [124]. NR2F1 over-expression in MCF-7 cells downregulates CXCL12 and up-regulates the corresponding receptor, CXCR4, via activation of the EGF-pathway. This increases $M C F-7$ cell-growth and cell-motility in response to CXCL12, suggesting a role for the NR2F1 in metastatic spread [125]. In breast-tumors, high NR2F2 mRNA levels are associated with better overall-survival 
and increased time-to-metastasis. NR2F2 silencing does not affect the growth/survival, while it increases $M C F-7$ and ER-/MDA-MB-231 cell-migration. NR2F2 inhibits TGF $\beta$-dependent EMT in both cell-lines [126]. NR2F2 down-regulation is associated with anti-estrogen resistance and NR2F2 over-expression reinstates sensitivity [127]. NR2F2 over-expression in ER-/MDA-MB435 cells causes growth-inhibition and G2/M phase arrest. Taken together the available results indicate that NR2F1 and NR2F2 are characterized by onco-suppressive properties in breast cancer, suggesting that strategies aimed at increasing their expression levels or aimed at stimulating their transcriptional activity are likely to be of therapeutic value. There are no studies on the significance of NR2F6 in mammary-tumors. However, given over-expression in all breast-cancer sub-types, NR2F6 may be a prooncogene.

\section{NR4A1 (NUR77:nuclear-receptor-related-77), NR4A2 (NURR1:nuclear-receptor-related-1) and NR4A3 (NOR-1:nuclear-orphan-receptor-1)}

NR4A1, NR4A2 and NR4A3 may control targetgene expression in a ligand-independent manner, acting as homodimers or RXR-heterodimers. NR4As are implicated in cell-cycle regulation, apoptosis, inflammation and metabolism [128]. The only known NR4A ligands/ activators are prostaglandin-A2 and 6-mercaptopurine which target NR4A3 (Table 3). NR4A1-mRNA is expressed in many tissues, including mammary-glands, although peripheral-nerves and adipose-tissue the highest levels (UNIGENE-Hs.524430). NR4A2-mRNA expression is restricted to bone-marrow, adrenal-glands, oviduct and sympathetic-ganglions,. The richest NR4A3 sources are adipose tissue, adrenal-glands and peripheral nerves (UNIGENE-Hs.279522). Mammary-glands contain similar levels of NR4A2 and NR4A3 transcripts.

Smaller NR4A1-mRNA amounts are observed in all PAM50 mammary-tumor types relative to the normal gland (Figure 5). Luminal-A and Normal-like show higher NR4A1 mRNA levels than Luminal-B tumors. NR4A1agonists induce apoptosis in mammary-tumor cells [129], although NR4A1 apoptotic activity is not necessarily related to NR4A1 transcriptional activity. In $\mathrm{ER}^{+} / M C F$ 7 cells, the apoptotic action of a natural coumarin and Plexin-D1 [130] requires $J N K$-dependent phosphorylation of NR4A1 and translocation from the nucleus to the cytoplasm, where the NR binds and inhibits BCL-2. NR4A1 activation reduces breast-cancer cell-migration, [131], although NR4A1-silencing inhibits TGF- $\beta$-induced EMT suggesting an opposite effect. The effect on EMT is consistent with the observation that inflammatory cytokines induce NR4A1 and enhance TGF- $\beta$-dependent breast-cancer cell-invasiveness in-vitro and in-vivo. Thus, NR4A1 induction/activation may reduce breast- cancer growth, although this beneficial effect may be counterbalanced by increased metastatic-spread.

NR4A2-mRNA is down-regulated in all PAM50 sub-types relative to the normal mammary tissue and, consistent with data obtained at the protein level [132], Basal tumors contain the smallest NR4A2 amounts (Figure 5). In primary breast-cancer, NR4A2 expression is inversely correlated with lymph-node metastases and directly correlated with increased relapse-free survival, suggesting onco-suppressive properties. In spite of this, NR4A2 silencing in Basal cell-lines decreases xenograft growth [133]. NR4A2 inhibits aromatase expression in mammary-gland stromal adipocytes [134] and this action may have implications for breast-cancer prevention, as obesity and estrogen production are breast-cancer riskfactors. The few data available in mammary-tumors support therapeutic strategies based on NR4A2-agonists. As the NR4A2 E-region is occupied by hydrophobic molecules, which prevents synthetic ligand accessibility [135], the observation that 6-mercaptopurine activates NR4As by targeting the N-terminal portion discloses new avenues in the design of agonists [136].

Although NR4A3-mRNA is generally downregulated in breast-cancer relative to the normal gland, Basal contain larger amounts than Luminal-A or Luminal-B tumors (Figure 5), confirming the results of a study showing NR4A3 up-regulation in $T N$ relative to Luminal breast-tumors [137]. This suggests an oncosuppressive role of NR4A3 in mammary-tissue, consistent with the NR4A3 growth-inhibitory action in other cellular contexts [138, 139]. Onco-suppression in breast-cancer is supported by NR4A3 up-regulation during apoptosis in $M C F-7$ cells [140]. NR4A3 induction in $M C F-7$ cells by the cyto-differentiating agent, ATRA, is also consistent with NR4A3 onco-suppressive potential [141].

\section{NR6A1 (GCNF:germ-cell-nuclear-factor)}

NR6A1 plays a crucial role in embryonic-stem-cell (ESC) homeostasis [142]. In ESC, NR6A1 is a positive determinant of pluripotency being down-regulated by the differentiating-agent, ATRA [99]. In adults, NR6A1-mRNA tissue-specific expression is limited to ovary and testis (UNIGENE-Hs.586460). Mammaryglands contain very low amounts of NR6A1 which are generally up-regulated in breast-cancer (Figure 5). The PAM50 subtypes showing the highest levels of NR6A1 up-regulation are Basal and Luminal-B tumors. The first observation is supported by a recent study indicating NR6A1 gene-expression enrichment in $\mathrm{TN} /$ and $\mathrm{ER}^{+} /$ tumors [143]. These data suggest that NR6A1 may be endowed with oncogenic properties in breast-cancer. 


\section{CONCLUSION}

Integration of the expression and functional data available allows a reliable prediction of the oncosuppressive or oncogenic role played by many of the NRs considered in breast-cancer (Tables 1, 2, 3). Within the Lipid-Sensors group, NR1C3, NR1H2 and NR1H3 are likely to play an onco-suppressive action. NR1F1, NR2A1 and NR3B3 (Enigmatic-Orphans) as well as NR0B1, NR0B2, NR1D1, NR2F1, NR2F2 and NR4A3 (Orphan-Receptors) seem to exert a similar activity. These NRs represent viable candidates for the development of therapeutic strategies aimed at increasing their expression or activating them in tumor cells. The availability of pharmacological agonists for NR1C3, NR1H2, NR1H3, NR1F1, NR0B2, and NR4A3 should boost pre-clinical studies in this direction. For all the remaining NRs, efforts should be oriented towards the design and synthesis of selective and high-affinity agonists. Except for NR1D1 and NR2F1, whose levels are significantly lower in Basallike relative to the other PAM50 subgroups, the expression profiles of the transcripts encoding the above mentioned NRs do not indicate any expression specificity in terms of breast-cancer subtypes. Nevertheless, as indicated in Table 2 and on the basis of the available literature, NR1F1 may be of particular significance as a therapeutic target in ER breast cancer. The group of NRs endowed with potential oncogenic properties in breast-cancer is smaller and consists of the Lipid-Sensors, NR1C2 and NR1I2, the Enigmatic-Orphans, NR1F3, NR3B1 and NR5A2, as well as the Orphan-Receptors, NR2E1, NR2E3 and NR6A1. To obtain anti-tumor effects, oncogenic NRs should be targeted with selective antagonists, reverseagonists or agents/strategies capable of reducing their expression in breast-cancer cells. At present only synthetic antagonists targeting NR1C2, NR1I2 and NR1F3 are available. On the basis of the expression profiles in the PAM50 subgroups, we propose that NR1C2, NR1I2 and NR2E1 are pharmacological targets of particular interest in Basal-like tumors. In the case of NR2E1, this is line with the evidence present in the literature which indicates that targeting of the receptor is particularly promising in ER - mammary tumors [121]. A similar relevance in ER is predicted also for NR1F3, as indicated in Table 2. Similar considerations suggest that NR1C2 and NR3B1 may be a useful targets in Her 2 breast cancer as well (Tables 1, 2). Finally the interest of NR3B1 may not be limited to this last group, as it may extend to ER- mammary tumors regardless of HER2-positivity (Table 2).

In the case of both onco-suppressive and oncogenic NRs there are some general points that should be considered and were touched upon in this review. Studies focusing on NR-targeting should be aimed at establishing the therapeutic potential in specific types of breast cancer given the heterogeneity of the disease. It is, indeed, highly unlikely that each of the identified NRs plays the same role in all mammary tumor-subtypes and targeting it results in similar anti-tumor effects, as recently demonstrated for the activation of RARs by ATRA and derived retinoids [5]. Thus, studies should not be limited to evaluating differential effects in the $\mathrm{ER}^{+} /$and $\mathrm{ER}^{-} /$cellular context, as traditionally done, but should take into consideration other identified breast cancer sub-groups such as the PAM50 classes used in this review. In addition, when different protein-variants of a specific NR are known, it is important to gather information as to the specific forms predominantly expressed in each breast-cancer subtype. In fact, this type of information is not available and should be gathered, as different protein-variants may have opposite effects in terms of oncogenic or onco-suppressive activity. Finally, the side effects potentially triggered by targeting a specific NR in breast-cancer should be considered before designing any targeted therapeutic strategy. With respect to this, a preliminary analysis of the data available on the tissue-distribution and physiological function of each NR is likely to be helpful in the selection of the specific NR to be targeted.

\section{ACKNOWLEDGMENTS}

The authors acknowledge the financial support of the Fondazione "Italo Monzino" and the Associazione Italiana per la Ricerca contro il Cancro (AIRC) that made this work possible. They also thank Silvio Garattini for critical reading of the manuscript as well as Felice Deceglie for the artwork.

\section{CONFLICTS OF INTEREST}

There is no conflict of interest.

\section{REFERENCES}

1. Rivenbark AG, O'Connor SM and Coleman WB. Molecular and cellular heterogeneity in breast cancer: challenges for personalized medicine. Am J Pathol. 2013; 183(4):11131124.

2. Evans RM and Mangelsdorf DJ. Nuclear Receptors, RXR, and the Big Bang. Cell. 2014; 157(1):255-266.

3. Sonoda J, Pei L and Evans RM. Nuclear receptors: decoding metabolic disease. FEBS Lett. 2008; 582(1):2-9.

4. Welsh J. Vitamin D and prevention of breast cancer. Acta Pharmacol Sin. 2007; 28(9):1373-1382.

5. Centritto F, Paroni G, Bolis M, Garattini SK, Kurosaki M, Barzago MM, Zanetti A, Fisher JN, Scott MF, Pattini L, Lupi M, Ubezio P, Piccotti F, Zambelli A, Rizzo P, Gianni M, et al. Cellular and molecular determinants of all-trans retinoic acid sensitivity in breast cancer: Luminal phenotype and RARalpha expression. EMBO Mol Med. 2015; 7(7):950-972. 
6. Leblanc BP and Stunnenberg HG. 9-cis retinoic acid signaling: changing partners causes some excitement. Genes Dev. 1995; 9(15):1811-1816.

7. Suchanek KM, May FJ, Robinson JA, Lee WJ, Holman NA, Monteith GR and Roberts-Thomson SJ. Peroxisome proliferator-activated receptor alpha in the human breast cancer cell lines MCF-7 and MDA-MB-231. Mol Carcinog. 2002; 34(4):165-171.

8. Papi A, Guarnieri T, Storci G, Santini D, Ceccarelli C, Taffurelli M, De Carolis S, Avenia N, Sanguinetti A, Sidoni A, Orlandi $\mathrm{M}$ and Bonafe $\mathrm{M}$. Nuclear receptors agonists exert opposing effects on the inflammation dependent survival of breast cancer stem cells. Cell Death Differ. 2012; 19(7):1208-1219.

9. Crowe DL and Chandraratna RA. A retinoid X receptor (RXR)-selective retinoid reveals that RXR-alpha is potentially a therapeutic target in breast cancer cell lines, and that it potentiates antiproliferative and apoptotic responses to peroxisome proliferator-activated receptor ligands. Breast Cancer Res. 2004; 6(5):R546-555.

10. Stephen RL, Gustafsson MC, Jarvis M, Tatoud R, Marshall BR, Knight D, Ehrenborg E, Harris AL, Wolf CR and Palmer CN. Activation of peroxisome proliferator-activated receptor delta stimulates the proliferation of human breast and prostate cancer cell lines. Cancer Res. 2004; 64(9):3162-3170.

11. Faddy HM, Robinson JA, Lee WJ, Holman NA, Monteith GR and Roberts-Thomson SJ. Peroxisome proliferatoractivated receptor alpha expression is regulated by estrogen receptor alpha and modulates the response of $\mathrm{MCF}-7$ cells to sodium butyrate. Int J Biochem Cell Biol. 2006; 38(2):255-266.

12. Zaveri NT, Sato BG, Jiang F, Calaoagan J, Laderoute KR and Murphy BJ. A novel peroxisome proliferator-activated receptor delta antagonist, SR13904, has anti-proliferative activity in human cancer cells. Cancer Biol Ther. 2009; 8(13):1252-1261.

13. Adhikary T, Brandt DT, Kaddatz K, Stockert J, Naruhn S, Meissner W, Finkernagel F, Obert J, Lieber S, Scharfe M, Jarek M, Toth PM, Scheer F, Diederich WE, Reinartz S, Grosse R, et al. Inverse PPARbeta/delta agonists suppress oncogenic signaling to the ANGPTL4 gene and inhibit cancer cell invasion. Oncogene. 2013; 32(44):5241-5252.

14. Yuan H, Lu J, Xiao J, Upadhyay G, Umans R, Kallakury B, Yin Y, Fant ME, Kopelovich L and Glazer RI. PPARdelta induces estrogen receptor-positive mammary neoplasia through an inflammatory and metabolic phenotype linked to mTOR activation. Cancer Res. 2013; 73(14):4349-4361.

15. Pollock CB, Yin Y, Yuan H, Zeng X, King S, Li X, Kopelovich L, Albanese C and Glazer RI. PPARdelta activation acts cooperatively with 3-phosphoinositidedependent protein kinase-1 to enhance mammary tumorigenesis. PLoS One. 2011; 6(1):e16215.

16. Kannan-Thulasiraman P, Seachrist DD, Mahabeleshwar GH, Jain MK and Noy N. Fatty acid-binding protein 5 and
PPARbeta/delta are critical mediators of epidermal growth factor receptor-induced carcinoma cell growth. J Biol Chem. 2010; 285(25):19106-19115.

17. Levi L, Lobo G, Doud MK, von Lintig J, Seachrist D, Tochtrop GP and Noy N. Genetic ablation of the fatty acid-binding protein FABP5 suppresses HER2-induced mammary tumorigenesis. Cancer Res. 2013; 73(15):47704780 .

18. Schug TT, Berry DC, Shaw NS, Travis SN and Noy N. Opposing effects of retinoic acid on cell growth result from alternate activation of two different nuclear receptors. Cell. 2007; 129(4):723-733.

19. Schug TT, Berry DC, Toshkov IA, Cheng L, Nikitin AY and Noy N. Overcoming retinoic acid-resistance of mammary carcinomas by diverting retinoic acid from PPARbeta/delta to RAR. Proc Natl Acad Sci U S A. 2008; 105(21):7546-7551.

20. Girroir EE, Hollingshead HE, Billin AN, Willson TM, Robertson GP, Sharma AK, Amin S, Gonzalez FJ and Peters JM. Peroxisome proliferator-activated receptor-beta/ delta (PPARbeta/delta) ligands inhibit growth of UACC903 and MCF7 human cancer cell lines. Toxicology. 2008; 243(1-2):236-243.

21. Yao PL, Morales JL, Zhu B, Kang BH, Gonzalez FJ and Peters JM. Activation of peroxisome proliferator-activated receptor-beta/delta (PPAR-beta/delta) inhibits human breast cancer cell line tumorigenicity. Mol Cancer Ther. 2014; 13(4):1008-1017.

22. Peters JM, Foreman JE and Gonzalez FJ. Dissecting the role of peroxisome proliferator-activated receptor-beta/delta (PPARbeta/delta) in colon, breast, and lung carcinogenesis. Cancer Metastasis Rev. 2011; 30(3-4):619-640.

23. Badawi AF and Badr MZ. Chemoprevention of breast cancer by targeting cyclooxygenase-2 and peroxisome proliferator-activated receptor-gamma (Review). Int $\mathrm{J}$ Oncol. 2002; 20(6):1109-1122.

24. Nwankwo JO and Robbins ME. Peroxisome proliferatoractivated receptor- gamma expression in human malignant and normal brain, breast and prostate-derived cells. Prostaglandins Leukot Essent Fatty Acids. 2001; 64(45):241-245.

25. Jarrar $\mathrm{MH}$ and Baranova A. PPARgamma activation by thiazolidinediones (TZDs) may modulate breast carcinoma outcome: the importance of interplay with TGFbeta signalling. J Cell Mol Med. 2007; 11(1):71-87.

26. Suh N, Wang Y, Williams CR, Risingsong R, Gilmer T, Willson TM and Sporn MB. A new ligand for the peroxisome proliferator-activated receptor-gamma (PPARgamma), GW7845, inhibits rat mammary carcinogenesis. Cancer Res. 1999; 59(22):5671-5673.

27. Mueller E, Sarraf P, Tontonoz P, Evans RM, Martin KJ, Zhang M, Fletcher C, Singer S and Spiegelman BM. Terminal differentiation of human breast cancer through PPAR gamma. Mol Cell. 1998; 1(3):465-470. 
28. Nunez NP, Liu H and Meadows GG. PPAR-gamma ligands and amino acid deprivation promote apoptosis of melanoma, prostate, and breast cancer cells. Cancer Lett. 2006; 236(1):133-141.

29. Fenner $\mathrm{MH}$ and Elstner E. Peroxisome proliferator-activated receptor-gamma ligands for the treatment of breast cancer. Expert Opin Investig Drugs. 2005; 14(6):557-568.

30. Mehta RG, Williamson E, Patel MK and Koeffler HP. A ligand of peroxisome proliferator-activated receptor gamma, retinoids, and prevention of preneoplastic mammary lesions. J Natl Cancer Inst. 2000; 92(5):418-423.

31. Nicol CJ, Yoon M, Ward JM, Yamashita M, Fukamachi K, Peters JM and Gonzalez FJ. PPARgamma influences susceptibility to DMBA-induced mammary, ovarian and skin carcinogenesis. Carcinogenesis. 2004; 25(9):17471755.

32. Pighetti GM, Novosad W, Nicholson C, Hitt DC, Hansens C, Hollingsworth AB, Lerner ML, Brackett D, Lightfoot SA and Gimble JM. Therapeutic treatment of DMBA-induced mammary tumors with PPAR ligands. Anticancer Res. 2001; 21(2A):825-829.

33. Saez E, Rosenfeld J, Livolsi A, Olson P, Lombardo E, Nelson M, Banayo E, Cardiff RD, Izpisua-Belmonte JC and Evans RM. PPAR gamma signaling exacerbates mammary gland tumor development. Genes Dev. 2004; 18(5):528540.

34. Burstein HJ, Demetri GD, Mueller E, Sarraf P, Spiegelman $\mathrm{BM}$ and Winer EP. Use of the peroxisome proliferatoractivated receptor (PPAR) gamma ligand troglitazone as treatment for refractory breast cancer: a phase II study. Breast Cancer Res Treat. 2003; 79(3):391-397.

35. Yee LD, Williams N, Wen P, Young DC, Lester J, Johnson MV, Farrar WB, Walker MJ, Povoski SP, Suster S and Eng C. Pilot study of rosiglitazone therapy in women with breast cancer: effects of short-term therapy on tumor tissue and serum markers. Clin Cancer Res. 2007; 13(1):246-252.

36. Fessler MB. Liver X Receptor: Crosstalk Node for the Signaling of Lipid Metabolism, Carbohydrate Metabolism, and Innate Immunity. Curr Signal Transduct Ther. 2008; $3(2): 75-81$.

37. Wada T, Kang HS, Angers M, Gong H, Bhatia S, Khadem S, Ren S, Ellis E, Strom SC, Jetten AM and Xie W. Identification of oxysterol 7alpha-hydroxylase (Cyp7b1) as a novel retinoid-related orphan receptor alpha (RORalpha) (NR1F1) target gene and a functional cross-talk between RORalpha and liver X receptor (NR1H3). Mol Pharmacol. 2008; 73(3):891-899.

38. Villablanca EJ, Raccosta L, Zhou D, Fontana R, Maggioni D, Negro A, Sanvito F, Ponzoni M, Valentinis B, Bregni M, Prinetti A, Steffensen KR, Sonnino S, Gustafsson JA, Doglioni C, Bordignon C, et al. Tumor-mediated liver X receptor-alpha activation inhibits $\mathrm{CC}$ chemokine receptor-7 expression on dendritic cells and dampens antitumor responses. Nat Med. 2010; 16(1):98-105.
39. Nelson ER, Chang CY and McDonnell DP. Cholesterol and breast cancer pathophysiology. Trends Endocrinol Metab. 2014; 25(12):649-655.

40. Nelson ER, Wardell SE, Jasper JS, Park S, Suchindran S, Howe MK, Carver NJ, Pillai RV, Sullivan PM, Sondhi V, Umetani M, Geradts J and McDonnell DP. 27-Hydroxycholesterol links hypercholesterolemia and breast cancer pathophysiology. Science. 2013; 342(6162):1094-1098.

41. Vedin LL, Lewandowski SA, Parini P, Gustafsson JA and Steffensen KR. The oxysterol receptor LXR inhibits proliferation of human breast cancer cells. Carcinogenesis. 2009; 30(4):575-579.

42. Nguyen-Vu T, Vedin LL, Liu K, Jonsson P, Lin JZ, Candelaria NR, Candelaria LP, Addanki S, Williams C, Gustafsson JA, Steffensen KR and Lin CY. Liver x receptor ligands disrupt breast cancer cell proliferation through an E2F-mediated mechanism. Breast Cancer Res. 2013; 15(3):R51.

43. Gong H, Guo P, Zhai Y, Zhou J, Uppal H, Jarzynka MJ, Song WC, Cheng SY and Xie W. Estrogen deprivation and inhibition of breast cancer growth in vivo through activation of the orphan nuclear receptor liver $\mathrm{X}$ receptor. Mol Endocrinol. 2007; 21(8):1781-1790.

44. El Roz A, Bard JM, Valin S, Huvelin JM and Nazih H. Macrophage apolipoprotein E and proliferation of MCF7 breast cancer cells: role of LXR. Anticancer Res. 2013; 33(9):3783-3789.

45. Makishima M, Okamoto AY, Repa JJ, Tu H, Learned RM, Luk A, Hull MV, Lustig KD, Mangelsdorf DJ and Shan B. Identification of a nuclear receptor for bile acids. Science. 1999; 284(5418):1362-1365.

46. Parks DJ, Blanchard SG, Bledsoe RK, Chandra G, Consler TG, Kliewer SA, Stimmel JB, Willson TM, Zavacki AM, Moore DD and Lehmann JM. Bile acids: natural ligands for an orphan nuclear receptor. Science. 1999; 284(5418):13651368.

47. Journe F, Durbecq V, Chaboteaux C, Rouas G, Laurent G, Nonclercq D, Sotiriou C, Body JJ and Larsimont D. Association between farnesoid $\mathrm{X}$ receptor expression and cell proliferation in estrogen receptor-positive luminal-like breast cancer from postmenopausal patients. Breast Cancer Res Treat. 2009; 115(3):523-535.

48. Carmichael AR. Obesity and prognosis of breast cancer. Obes Rev. 2006; 7(4):333-340.

49. Javitt NB, Budai K, Miller DG, Cahan AC, Raju $\mathrm{U}$ and Levitz M. Breast-gut connection: origin of chenodeoxycholic acid in breast cyst fluid. Lancet. 1994; 343(8898):633-635.

50. Silva J, Dasgupta S, Wang G, Krishnamurthy K, Ritter $\mathrm{E}$ and Bieberich E. Lipids isolated from bone induce the migration of human breast cancer cells. J Lipid Res. 2006; 47(4):724-733. 
51. Swales KE, Korbonits M, Carpenter R, Walsh DT, Warner $\mathrm{TD}$ and Bishop-Bailey D. The farnesoid $\mathrm{X}$ receptor is expressed in breast cancer and regulates apoptosis and aromatase expression. Cancer Res. 2006; 66(20):1012010126.

52. Giordano C, Catalano S, Panza S, Vizza D, Barone I, Bonofiglio D, Gelsomino L, Rizza P, Fuqua SA and Ando S. Farnesoid X receptor inhibits tamoxifen-resistant MCF-7 breast cancer cell growth through downregulation of HER2 expression. Oncogene. 2011; 30(39):4129-4140.

53. Qiao E, Ji M, Wu J, Ma R, Zhang X, He Y, Zha Q, Song $\mathrm{X}$, Zhu LW and Tang J. Expression of the PXR gene in various types of cancer and drug resistance. Oncol Lett. 2013; 5(4):1093-1100.

54. Rosenfeld JM, Vargas R, Jr., Xie W and Evans RM. Genetic profiling defines the xenobiotic gene network controlled by the nuclear receptor pregnane X receptor. Mol Endocrinol. 2003; 17(7):1268-1282.

55. Dotzlaw H, Leygue E, Watson $P$ and Murphy LC. The human orphan receptor PXR messenger RNA is expressed in both normal and neoplastic breast tissue. Clin Cancer Res. 1999; 5(8):2103-2107.

56. Conde I, Lobo MV, Zamora J, Perez J, Gonzalez FJ, Alba E, Fraile B, Paniagua R and Arenas MI. Human pregnane $\mathrm{X}$ receptor is expressed in breast carcinomas, potential heterodimers formation between hPXR and RXR-alpha. BMC Cancer. 2008; 8:174.

57. Choi HK, Yang JW, Roh SH, Han CY and Kang KW. Induction of multidrug resistance associated protein 2 in tamoxifen-resistant breast cancer cells. Endocr Relat Cancer. 2007; 14(2):293-303.

58. Qiao EQ and Yang HJ. Effect of pregnane X receptor expression on drug resistance in breast cancer. Oncol Lett. 2014; 7(4):1191-1196.

59. Fitzsimmons RL, Lau $P$ and Muscat GE. Retinoidrelated orphan receptor alpha and the regulation of lipid homeostasis. J Steroid Biochem Mol Biol. 2012; 130(35):159-168.

60. Jetten AM. Retinoid-related orphan receptors (RORs): critical roles in development, immunity, circadian rhythm, and cellular metabolism. Nucl Recept Signal. 2009; 7:e003.

61. Toyama H, Nakamura M, Matsumoto Y, Nakagomi M and Hashimoto Y. Development of novel silicon-containing inverse agonists of retinoic acid receptor-related orphan receptors. Bioorg Med Chem. 2014; 22(6):1948-1959.

62. Dong C, Yuan L, Dai J, Lai L, Mao L, Xiang S, Rowan $\mathrm{B}$ and Hill SM. Melatonin inhibits mitogenic crosstalk between retinoic acid-related orphan receptor alpha (RORalpha) and ERalpha in MCF-7 human breast cancer cells. Steroids. 2010; 75(12):944-951.

63. Odawara H, Iwasaki $\mathrm{T}$, Horiguchi J, Rokutanda $\mathrm{N}$, Hirooka K, Miyazaki W, Koibuchi Y, Shimokawa N, Iino Y, Takeyoshi I and Koibuchi N. Activation of aromatase expression by retinoic acid receptor-related orphan receptor
(ROR) alpha in breast cancer cells: identification of a novel ROR response element. J Biol Chem. 2009; 284(26):1771117719.

64. Benevides L, Cardoso CR, Tiezzi DG, Marana HR, Andrade JM and Silva JS. Enrichment of regulatory T cells in invasive breast tumor correlates with the upregulation of IL-17A expression and invasiveness of the tumor. Eur J Immunol. 2013; 43(6):1518-1528.

65. Chen Y, Tang Y, Guo C, Wang J, Boral D and Nie D. Nuclear receptors in the multidrug resistance through the regulation of drug-metabolizing enzymes and drug transporters. Biochem Pharmacol. 2012; 83(8):1112-1126.

66. Xiong $\mathrm{G}$ and $\mathrm{Xu}$ R. RORalpha binds to E2F1 to inhibit cell proliferation and regulate mammary gland branching morphogenesis. Mol Cell Biol. 2014; 34(16):3066-3075.

67. Cadenas C, van de Sandt L, Edlund K, Lohr M, Hellwig B, Marchan R, Schmidt M, Rahnenfuhrer J, Oster H and Hengstler JG. Loss of circadian clock gene expression is associated with tumor progression in breast cancer. Cell Cycle. 2014; 13(20):3282-3291.

68. Newman B, Lose F, Kedda MA, Francois M, Ferguson K, Janda M, Yates P, Spurdle AB and Hayes SC. Possible genetic predisposition to lymphedema after breast cancer. Lymphat Res Biol. 2012; 10(1):2-13.

69. Jyrkkarinne J, Makinen J, Gynther J, Savolainen H, Poso A and Honkakoski P. Molecular determinants of steroid inhibition for the mouse constitutive androstane receptor. J Med Chem. 2003; 46(22):4687-4695.

70. Goodwin B and Moore JT. CAR: detailing new models. Trends Pharmacol Sci. 2004; 25(8):437-441.

71. Huang W, Zhang J, Washington M, Liu J, Parant JM, Lozano $G$ and Moore DD. Xenobiotic stress induces hepatomegaly and liver tumors via the nuclear receptor constitutive androstane receptor. Mol Endocrinol. 2005; 19(6):1646-1653.

72. Bell AW and Michalopoulos GK. Phenobarbital regulates nuclear expression of HNF-4alpha in mouse and rat hepatocytes independent of CAR and PXR. Hepatology. 2006; 44(1):186-194.

73. Walesky C and Apte U. Role of hepatocyte nuclear factor 4alpha (HNF4alpha) in cell proliferation and cancer. Gene Expr. 2015; 16(3):101-108.

74. Yuan X, Ta TC, Lin M, Evans JR, Dong Y, Bolotin E, Sherman MA, Forman BM and Sladek FM. Identification of an endogenous ligand bound to a native orphan nuclear receptor. PLoS One. 2009; 4(5):e5609.

75. Taraviras S, Mantamadiotis T, Dong-Si T, Mincheva A, Lichter P, Drewes T, Ryffel GU, Monaghan AP and Schutz G. Primary structure, chromosomal mapping, expression and transcriptional activity of murine hepatocyte nuclear factor 4gamma. Biochim Biophys Acta. 2000; 1490(12):21-32.

76. Sladek F. Desperately seeking...something. Mol Cell. 2002; 10(2):219-221. 
77. Alotaibi H, Basilicata MF, Shehwana H, Kosowan T, Schreck I, Braeutigam C, Konu O, Brabletz T and Stemmler MP. Enhancer cooperativity as a novel mechanism underlying the transcriptional regulation of E-cadherin during mesenchymal to epithelial transition. Biochim Biophys Acta. 2015; 1849(6):731-742.

78. Angrand PO, Coffinier $\mathrm{C}$ and Weiss MC. Response of the phosphoenolpyruvate carboxykinase gene to glucocorticoids depends on the integrity of the cAMP pathway. Cell Growth Differ. 1994; 5(9):957-966.

79. Kim HJ, Lee SK, Na SY, Choi HS and Lee JW. Molecular cloning of xSRC-3, a novel transcription coactivator from Xenopus, that is related to AIB1, p/CIP, and TIF2. Mol Endocrinol. 1998; 12(7):1038-1047.

80. Moldrup A, Ormandy C, Nagano M, Murthy K, Banville D, Tronche F and Kelly PA. Differential promoter usage in prolactin receptor gene expression: hepatocyte nuclear factor 4 binds to and activates the promoter preferentially active in the liver. Mol Endocrinol. 1996; 10(6):661-671.

81. Svoboda M, Riha J, Wlcek K, Jaeger W and Thalhammer T. Organic anion transporting polypeptides (OATPs): regulation of expression and function. Curr Drug Metab. 2011; 12(2):139-153.

82. Deblois G and Giguere V. Oestrogen-related receptors in breast cancer: control of cellular metabolism and beyond. Nat Rev Cancer. 2013; 13(1):27-36.

83. Deblois G, Hall JA, Perry MC, Laganiere J, Ghahremani M, Park M, Hallett M and Giguere V. Genome-wide identification of direct target genes implicates estrogenrelated receptor alpha as a determinant of breast cancer heterogeneity. Cancer Res. 2009; 69(15):6149-6157.

84. Dufour CR, Levasseur MP, Pham NH, Eichner LJ, Wilson BJ, Charest-Marcotte A, Duguay D, Poirier-Heon JF, Cermakian N and Giguere V. Genomic convergence among ERRalpha, PROX1, and BMAL1 in the control of metabolic clock outputs. PLoS Genet. 2011; 7(6):e1002143.

85. Mootha VK, Handschin C, Arlow D, Xie X, St Pierre J, Sihag S, Yang W, Altshuler D, Puigserver P, Patterson N, Willy PJ, Schulman IG, Heyman RA, Lander ES and Spiegelman BM. Erralpha and Gabpa/b specify PGC-1alpha-dependent oxidative phosphorylation gene expression that is altered in diabetic muscle. Proc Natl Acad Sci U S A. 2004; 101(17):6570-6575.

86. Huss JM, Torra IP, Staels B, Giguere V and Kelly DP. Estrogen-related receptor alpha directs peroxisome proliferator-activated receptor alpha signaling in the transcriptional control of energy metabolism in cardiac and skeletal muscle. Mol Cell Biol. 2004; 24(20):9079-9091.

87. Ariazi EA, Clark GM and Mertz JE. Estrogen-related receptor alpha and estrogen-related receptor gamma associate with unfavorable and favorable biomarkers, respectively, in human breast cancer. Cancer Res. 2002; 62(22):6510-6518.

88. Ariazi EA, Kraus RJ, Farrell ML, Jordan VC and Mertz JE.
Estrogen-related receptor alpha1 transcriptional activities are regulated in part via the ErbB2/HER2 signaling pathway. Mol Cancer Res. 2007; 5(1):71-85.

89. Deblois G, Chahrour G, Perry MC, Sylvain-Drolet G, Muller WJ and Giguere V. Transcriptional control of the ERBB2 amplicon by ERRalpha and PGC-1beta promotes mammary gland tumorigenesis. Cancer Res. 2010; 70(24):10277-10287.

90. Ariazi EA and Jordan VC. Estrogen-related receptors as emerging targets in cancer and metabolic disorders. Curr Top Med Chem. 2006; 6(3):203-215.

91. Stein RA, Chang CY, Kazmin DA, Way J, Schroeder T, Wergin M, Dewhirst MW and McDonnell DP. Estrogenrelated receptor alpha is critical for the growth of estrogen receptor-negative breast cancer. Cancer Res. 2008; 68(21):8805-8812.

92. Dwyer MA, Joseph JD, Wade HE, Eaton ML, Kunder RS, Kazmin D, Chang CY and McDonnell DP. WNT11 expression is induced by estrogen-related receptor alpha and beta-catenin and acts in an autocrine manner to increase cancer cell migration. Cancer Res. 2010; 70(22):9298-9308.

93. Stein RA, Gaillard S and McDonnell DP. Estrogenrelated receptor alpha induces the expression of vascular endothelial growth factor in breast cancer cells. J Steroid Biochem Mol Biol. 2009; 114(1-2):106-112.

94. Vadlamudi RK, Rajhans R, Chakravarty D, Nair BC, Nair SS, Evans DB, Chen S and Tekmal RR. Regulation of aromatase induction by nuclear receptor coregulator PELP1. J Steroid Biochem Mol Biol. 2010; 118(4-5):211218.

95. Sengupta D, Bhargava DK, Dixit A, Sahoo BS, Biswas S, Biswas G and Mishra SK. ERRbeta signalling through FST and BCAS2 inhibits cellular proliferation in breast cancer cells. Br J Cancer. 2014; 110(8):2144-2158.

96. Eichner LJ, Perry MC, Dufour CR, Bertos N, Park M, StPierre J and Giguere V. miR-378( *) mediates metabolic shift in breast cancer cells via the PGC-1beta/ERRgamma transcriptional pathway. Cell Metab. 2010; 12(4):352-361.

97. Tiraby C, Hazen BC, Gantner ML and Kralli A. Estrogenrelated receptor gamma promotes mesenchymal-toepithelial transition and suppresses breast tumor growth. Cancer Res. 2011; 71(7):2518-2528.

98. Schimmer BP and White PC. Minireview: steroidogenic factor 1: its roles in differentiation, development, and disease. Mol Endocrinol. 2010; 24(7):1322-1337.

99. Annicotte JS, Chavey C, Servant N, Teyssier J, Bardin A, Licznar A, Badia E, Pujol P, Vignon F, Maudelonde T, Lazennec G, Cavailles V and Fajas L. The nuclear receptor liver receptor homolog-1 is an estrogen receptor target gene. Oncogene. 2005; 24(55):8167-8175.

100. Miki Y, Clyne CD, Suzuki T, Moriya T, Shibuya R, Nakamura Y, Ishida T, Yabuki N, Kitada K, Hayashi $\mathrm{S}$ and Sasano H. Immunolocalization of liver receptor homologue-1 (LRH-1) in human breast carcinoma: possible 
regulator of insitu steroidogenesis. Cancer Lett. 2006; 244(1):24-33.

101. Thiruchelvam PT, Lai CF, Hua H, Thomas RS, Hurtado A, Hudson W, Bayly AR, Kyle FJ, Periyasamy M, Photiou A, Spivey AC, Ortlund EA, Whitby RJ, Carroll JS, Coombes $\mathrm{RC}$, Buluwela L, et al. The liver receptor homolog-1 regulates estrogen receptor expression in breast cancer cells. Breast Cancer Res Treat. 2011; 127(2):385-396.

102. Chand AL, Wijayakumara DD, Knower KC, Herridge KA, Howard TL, Lazarus KA and Clyne CD. The orphan nuclear receptor LRH-1 and ERalpha activate GREB1 expression to induce breast cancer cell proliferation. PLoS One. 2012; 7(2):e31593.

103. Chand AL, Herridge KA, Thompson EW and Clyne CD. The orphan nuclear receptor LRH-1 promotes breast cancer motility and invasion. Endocr Relat Cancer. 2010; 17(4):965-975.

104. Bianco S, Brunelle M, Jangal M, Magnani L and Gevry N. LRH-1 governs vital transcriptional programs in endocrinesensitive and -resistant breast cancer cells. Cancer Res. 2014; 74(7):2015-2025.

105. Lalli E and Alonso J. Targeting DAX-1 in embryonic stem cells and cancer. Expert Opin Ther Targets. 2010; 14(2):169-177.

106. Zhang H, Slewa A, Janssen E, Skaland I, Yu Y, Gudlaugsson E, Feng W, Kjellevold K, Soiland H and Baak JP. The prognostic value of the orphan nuclear receptor DAX-1 (NROB1) in node-negative breast cancer. Anticancer Res. 2011; 31(2):443-449.

107. Chae BJ, Lee A, Bae JS, Song BJ and Jung SS. Expression of nuclear receptor DAX-1 and androgen receptor in human breast cancer. J Surg Oncol. 2011; 103(8):768-772.

108. Lanzino M, Maris P, Sirianni R, Barone I, Casaburi I, Chimento A, Giordano C, Morelli C, Sisci D, Rizza P, Bonofiglio D, Catalano S and Ando S. DAX-1, as an androgen-target gene, inhibits aromatase expression: a novel mechanism blocking estrogen-dependent breast cancer cell proliferation. Cell Death Dis. 2013; 4:e724.

109. Farhana L, Dawson MI, Leid M, Wang L, Moore DD, Liu G, Xia Z and Fontana JA. Adamantyl-substituted retinoid-related molecules bind small heterodimer partner and modulate the Sin3A repressor. Cancer Res. 2007; 67(1):318-325.

110. Burris TP. Nuclear hormone receptors for heme: REVERBalpha and REV-ERBbeta are ligand-regulated components of the mammalian clock. Mol Endocrinol. 2008; 22(7):1509-1520.

111. Duez H and Staels B. Rev-erb alpha gives a time cue to metabolism. FEBS Lett. 2008; 582(1):19-25.

112. Kourtidis A, Jain R, Carkner RD, Eifert C, Brosnan MJ and Conklin DS. An RNA interference screen identifies metabolic regulators NR1D1 and PBP as novel survival factors for breast cancer cells with the ERBB2 signature. Cancer Res. 2010; 70(5):1783-1792.
113. Shyr CR, Kang HY, Tsai MY, Liu NC, Ku PY, Huang KE and Chang C. Roles of testicular orphan nuclear receptors 2 and 4 in early embryonic development and embryonic stem cells. Endocrinology. 2009; 150(5):2454-2462.

114. Hu YC, Shyr CR, Che W, Mu XM, Kim E and Chang C. Suppression of estrogen receptor-mediated transcription and cell growth by interaction with TR2 orphan receptor. J Biol Chem. 2002; 277(37):33571-33579.

115. Gupta P, Park SW, Farooqui M and Wei LN. Orphan nuclear receptor TR2, a mediator of preadipocyte proliferation, is differentially regulated by RA through exchange of coactivator PCAF with corepressor RIP140 on a platform molecule GRIP1. Nucleic Acids Res. 2007; 35(7):2269-2282.

116. Gupta P, Ho PC, Huq MM, Ha SG, Park SW, Khan AA, Tsai NP and Wei LN. Retinoic acid-stimulated sequential phosphorylation, PML recruitment, and SUMOylation of nuclear receptor TR2 to suppress Oct4 expression. Proc Natl Acad Sci U S A. 2008; 105(32):11424-11429.

117. Mu X and Chang C. TR2 orphan receptor functions as negative modulator for androgen receptor in prostate cancer cells PC-3. Prostate. 2003; 57(2):129-133.

118. Shi Y, Chichung Lie D, Taupin P, Nakashima K, Ray J, Yu RT, Gage FH and Evans RM. Expression and function of orphan nuclear receptor TLX in adult neural stem cells. Nature. 2004; 427(6969):78-83.

119. Cheng H, Khanna H, Oh EC, Hicks D, Mitton KP and Swaroop A. Photoreceptor-specific nuclear receptor NR2E3 functions as a transcriptional activator in rod photoreceptors. Hum Mol Genet. 2004; 13(15):1563-1575.

120. O'Loghlen A, Martin N, Krusche B, Pemberton H, Alonso MM, Chandler H, Brookes S, Parrinello S, Peters G and Gil J. The nuclear receptor NR2E1/TLX controls senescence. Oncogene. 2015; 34(31):4069-4077.

121. Lin ML, Patel H, Remenyi J, Banerji CR, Lai CF, Periyasamy M, Lombardo Y, Busonero C, Ottaviani S, Passey A, Quinlan PR, Purdie CA, Jordan LB, Thompson AM, Finn RS, Rueda OM, et al. Expression profiling of nuclear receptors in breast cancer identifies TLX as a mediator of growth and invasion in triple-negative breast cancer. Oncotarget. 2015; 6(25):21685-21703. doi: 10.18632/oncotarget.3942.

122. Zhao Z, Wang L and Xu W. IL-13Ralpha2 mediates PNRinduced migration and metastasis in ERalpha-negative breast cancer. Oncogene. 2015; 34(12):1596-1607.

123. Metivier R, Gay FA, Hubner MR, Flouriot G, Salbert G, Gannon F, Kah O and Pakdel F. Formation of an hER alpha-COUP-TFI complex enhances hER alpha AF-1 through Ser118 phosphorylation by MAPK. EMBO J. 2002; 21(13):3443-3453.

124. Kim RS, Avivar-Valderas A, Estrada Y, Bragado P, Sosa MS, Aguirre-Ghiso JA and Segall JE. Dormancy signatures and metastasis in estrogen receptor positive and negative breast cancer. PLoS One. 2012; 7(4):e35569. 
125. Boudot A, Kerdivel G, Lecomte S, Flouriot G, Desille M, Godey F, Leveque J, Tas P, Le Drean Y and Pakdel F. COUP-TFI modifies CXCL12 and CXCR4 expression by activating EGF signaling and stimulates breast cancer cell migration. BMC Cancer. 2014; 14:407.

126. Zhang C, Han Y, Huang H, Qu L and Shou C. High NR2F2 transcript level is associated with increased survival and its expression inhibits TGF-beta-dependent epithelialmesenchymal transition in breast cancer. Breast Cancer Res Treat. 2014; 147(2):265-281.

127. Nakshatri H, Mendonca MS, Bhat-Nakshatri P, Patel NM, Goulet RJ, Jr. and Cornetta K. The orphan receptor COUPTFII regulates G2/M progression of breast cancer cells by modulating the expression/activity of p21(WAF1/CIP1), cyclin D1, and cdk2. Biochem Biophys Res Commun. 2000; 270(3):1144-1153.

128. Deutsch AJ, Angerer H, Fuchs TE and Neumeister P. The nuclear orphan receptors NR4A as therapeutic target in cancer therapy. Anticancer Agents Med Chem. 2012; 12(9):1001-1014.

129. Chintharlapalli S, Burghardt R, Papineni S, Ramaiah S, Yoon K and Safe S. Activation of Nur77 by selected 1,1-Bis(3'-indolyl)-1-(p-substituted phenyl)methanes induces apoptosis through nuclear pathways. J Biol Chem. 2005; 280(26):24903-24914.

130. Luchino J, Hocine M, Amoureux MC, Gibert B, Bernet A, Royet A, Treilleux I, Lecine P, Borg JP, Mehlen P, Chauvet $\mathrm{S}$ and Mann F. Semaphorin 3E suppresses tumor cell death triggered by the plexin D1 dependence receptor in metastatic breast cancers. Cancer Cell. 2013; 24(5):673685 .

131. Alexopoulou AN, Leao M, Caballero OL, Da Silva L, Reid L, Lakhani SR, Simpson AJ, Marshall JF, Neville AM and Jat PS. Dissecting the transcriptional networks underlying breast cancer: NR4A1 reduces the migration of normal and breast cancer cell lines. Breast Cancer Res. 2010; 12(4):R51.

132. Llopis S, Singleton B, Duplessis T, Carrier L, Rowan B and Williams C. Dichotomous roles for the orphan nuclear receptor NURR1 in breast cancer. BMC Cancer. 2013; 13:139.

133. Safe S, Jin UH, Hedrick E, Reeder A and Lee SO. Minireview: role of orphan nuclear receptors in cancer and potential as drug targets. Mol Endocrinol. 2014; 28(2):157172.
134. Ghosh S, Hu Y and Li R. Cell density is a critical determinant of aromatase expression in adipose stromal cells. J Steroid Biochem Mol Biol. 2010; 118(4-5):231-236.

135. Wang Z, Benoit G, Liu J, Prasad S, Aarnisalo P, Liu X, $\mathrm{Xu} \mathrm{H}$, Walker NP and Perlmann T. Structure and function of Nurr1 identifies a class of ligand-independent nuclear receptors. Nature. 2003; 423(6939):555-560.

136. Wansa KD, Harris JM, Yan G, Ordentlich P and Muscat GE. The AF-1 domain of the orphan nuclear receptor NOR1 mediates trans-activation, coactivator recruitment, and activation by the purine anti-metabolite 6-mercaptopurine. J Biol Chem. 2003; 278(27):24776-24790.

137. Yuan ZY, Dai T, Wang SS, Peng RJ, Li XH, Qin T, Song LB and Wang X. Overexpression of ETV4 protein in triplenegative breast cancer is associated with a higher risk of distant metastasis. Onco Targets Ther. 2014; 7:1733-1742.

138. Hardy K, Mansfield L, Mackay A, Benvenuti S, Ismail S, Arora P, O'Hare MJ and Jat PS. Transcriptional networks and cellular senescence in human mammary fibroblasts. Mol Biol Cell. 2005; 16(2):943-953.

139. Martinez-Gonzalez J, Rius J, Castello A, Cases-Langhoff C and Badimon L. Neuron-derived orphan receptor-1 (NOR1) modulates vascular smooth muscle cell proliferation. Circ Res. 2003; 92(1):96-103.

140. Ohkubo T, Ohkura N, Maruyama K, Sasaki K, Nagasaki K, Hanzawa H, Tsukada T and Yamaguchi K. Early induction of the orphan nuclear receptor NOR-1 during cell death of the human breast cancer cell line MCF-7. Mol Cell Endocrinol. 2000; 162(1-2):151-156.

141. Maruyama K, Tsukada T, Bandoh S, Sasaki K, Ohkura N and Yamaguchi $\mathrm{K}$. Retinoic acids differentially regulate NOR-1 and its closely related orphan nuclear receptor genes in breast cancer cell line MCF-7. Biochem Biophys Res Commun. 1997; 231(2):417-420.

142. Zechel C. The germ cell nuclear factor (GCNF). Mol Reprod Dev. 2005; 72(4):550-556.

143. Willis S, De P, Dey N, Long B, Young B, Sparano JA, Wang V, Davidson NE and Leyland-Jones BR. Enriched transcription factor signatures in triple negative breast cancer indicates possible targeted therapies with existing drugs. Meta Gene. 2015; 4:129-141. 